Prepared in cooperation with the Mid-Columbia Fisheries Enhancement Group

\title{
Juvenile Salmonid Monitoring Following Removal of Condit Dam in the White Salmon River Watershed, Washington, 2017
}

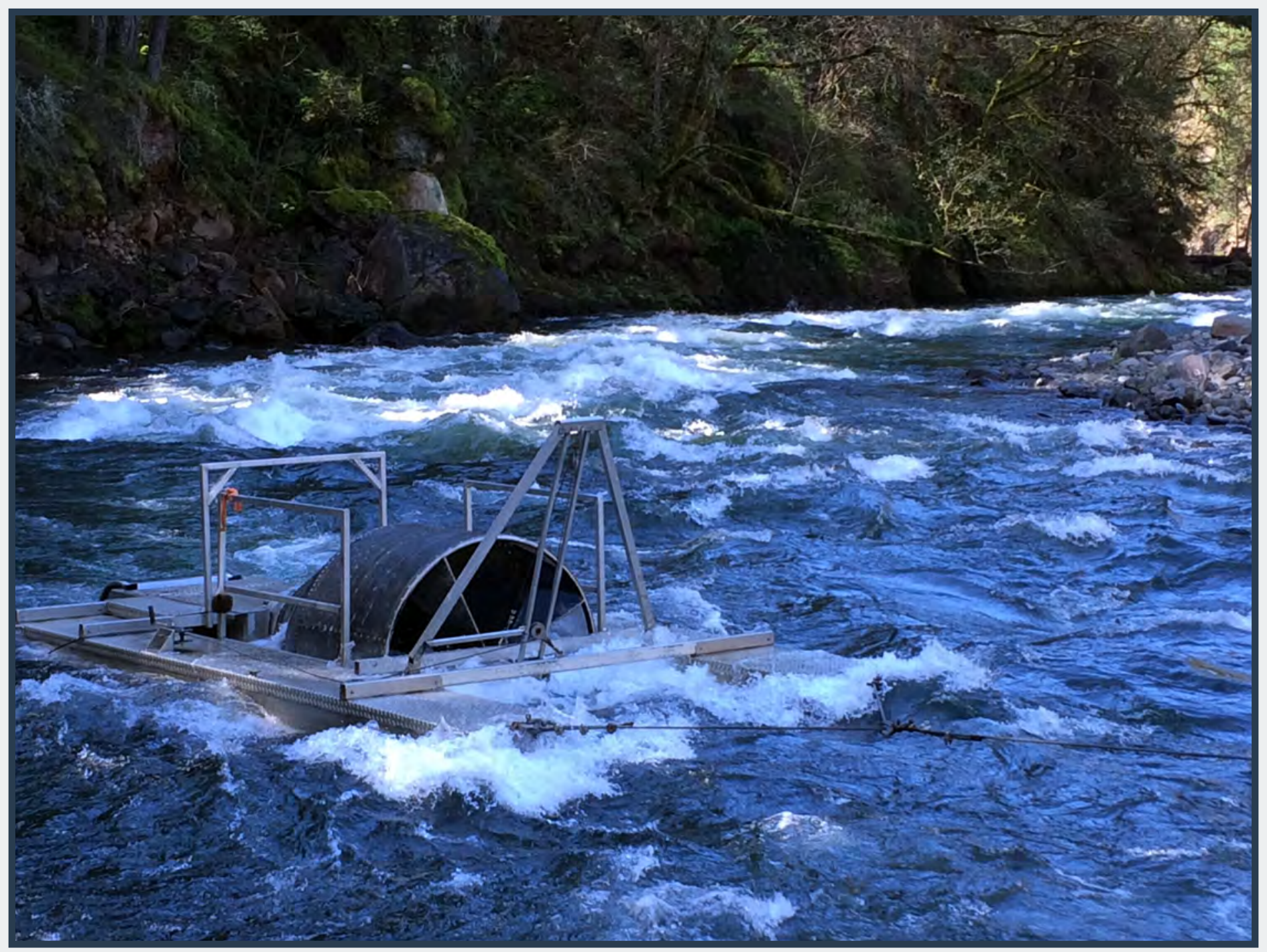

Open-File Report 2018-1106

U.S. Department of the Interior U.S. Geological Survey 
Cover: Photograph of rotary screw trap at river kilometer 2.3, White Salmon River, Washington. Photograph by U.S. Geological Survey, March 28, 2016. 


\section{Juvenile Salmonid Monitoring Following Removal of Condit Dam in the White Salmon River Watershed, Washington, 2017}

By lan G. Jezorek and Jill M. Hardiman

Prepared in cooperation with the Mid-Columbia Fisheries Enhancement Group

Open-File Report 2018-1106

U.S. Department of the Interior

U.S. Geological Survey 


\section{U.S. Department of the Interior \\ RYAN K. ZINKE, Secretary}

\section{U.S. Geological Survey \\ James F. Reilly II, Director}

U.S. Geological Survey, Reston, Virginia: 2018

For more information on the USGS—-the Federal source for science about the Earth, its natural and living resources, natural hazards, and the environment-visit https://www.usgs.gov/ or call 1-888-ASK-USGS (1-888-275-8747).

For an overview of USGS information products, including maps, imagery, and publications, visit https:/store.usgs.gov.

Any use of trade, firm, or product names is for descriptive purposes only and does not imply endorsement by the U.S. Government.

Although this information product, for the most part, is in the public domain, it also may contain copyrighted materials as noted in the text. Permission to reproduce copyrighted items must be secured from the copyright owner.

Suggested citation:

Jezorek, I.G., and Hardiman, J.M., 2018, Juvenile salmonid monitoring following removal of Condit Dam in the White Salmon River watershed, Washington, 2017: U.S. Geological Survey Open-File Report 2018-1106, 31 p. https://doi.org/10.3133/ofr20181106.

ISSN 2331-1258 (online) 


\section{Contents}

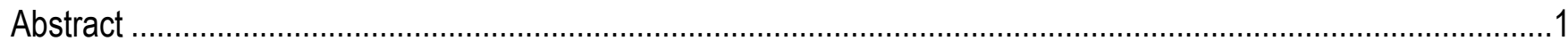

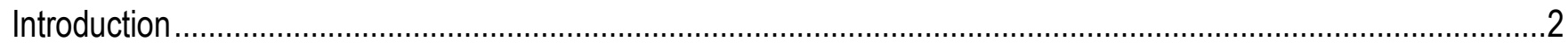

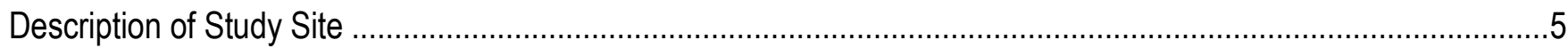

Study Methods

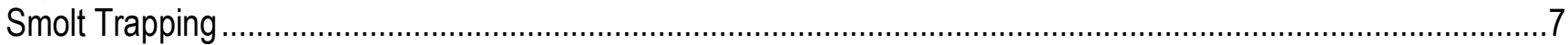

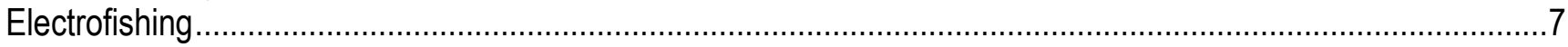

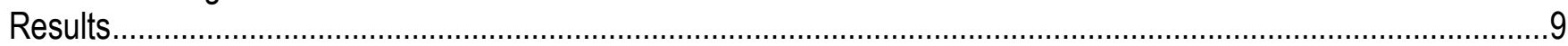

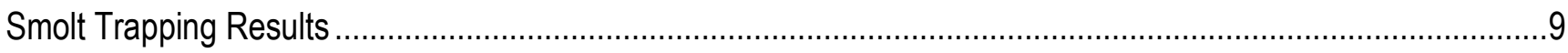

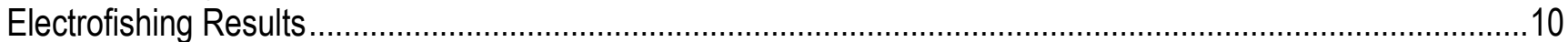

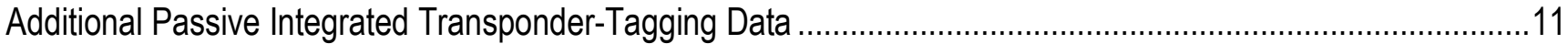

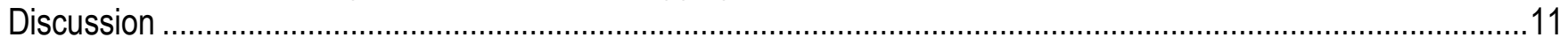

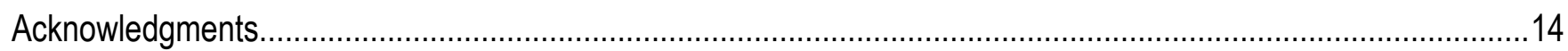

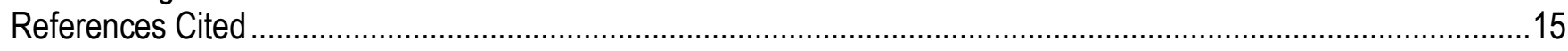

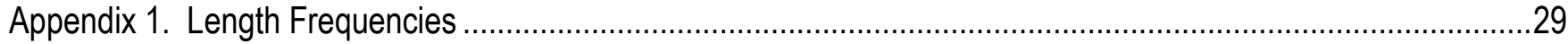

\section{Figures}

Figure 1. Schematic of the White Salmon River watershed accessible to anadromous salmonids showing locations of rotary screw trapping and electrofishing surveys during 2017 and the former location of Condit Dam, which was breached in 2011

Figure 2. Graphs showing daily catch of steelhead (Oncorhynchus mykiss) fry, parr, and smolts in the screw trap at river kilometer 2.3, White Salmon River, Washington, April 11-June 12, 2017.

Figure 3. Graphs showing daily catch of coho salmon (Oncorhynchus kisutch) fry, parr, and smolt in the screw trap at river kilometer 2.3, White Salmon River, Washington, April 11-June 12, 2017

Figure 4. Graph showing daily catch of Chinook salmon (Oncorhynchus tshwaytscha) fry and parr in the screw trap at river kilometer 2.3, White Salmon River, Washington, April 11-June 12, 2017.

Figure 5. Graphs showing fish-per-day of steelhead (Oncorhynchus mykiss), coho salmon (0. kisutch), and Chinook salmon (0. tshwaytscha) at a screw trap fished prior to (2007-09) and after (2016-17) removal of Condit Dam, White Salmon River, Washington

Figure 6. Graph showing abundance estimates of steelhead/rainbow trout (Oncorhynchus mykiss) and coho salmon (O. kisutch) at a site on the lower kilometer of Rattlesnake Creek, Washington, 2001-05 and 2016-17.....

Figure 7. Graph showing abundance estimates of steelhead/rainbow trout (Oncorhynchus mykiss) and coho salmon (O. kisutch) at a sample site in river kilometer 2 of Buck Creek, Washington, 2009-10 and 2016-17. 


\section{Tables}

Table 1. Latitude and longitude of fish sampling sites, White Salmon River watershed, Washington, 2017

Table 2. Number of steelhead (Oncorhynchus mykiss), Chinook salmon (O. tshawytscha), and coho salmon ( 0 . kisutch), by life stage, captured, tagged with passive integrated transponder tags, and sampled for genetic material at the screw trap at river kilometer 2.3, White Salmon River, Washington,

April 11, 2017-June 12, 2017.

Table 3. Number of steelhead (Oncorhynchus mykiss) and coho salmon (O. kisutch) smolt, and age-0

Chinook salmon captured, marked, and recaptured at the smolt trap at river kilometer 2.3, White Salmon

River, Washington, March 24-May 28, 2016, and April 11-June 12, 2017

Table 4. Number of juvenile salmonids captured and tagged with passive integrated transponder tags, and tissue sampled for genetic analysis during electrofishing surveys, White Salmon River watershed, Washington, 2017.

Table 5. Abundance estimates and standard error, abundance and density of steelhead/rainbow trout (Oncorhynchus mykiss) and coho salmon (O. kisutch) at abundance electrofishing sites in Buck and Rattlesnake Creeks, Washington, August 2017. 


\section{Conversion Factors}

U.S. customary units to International System of Units

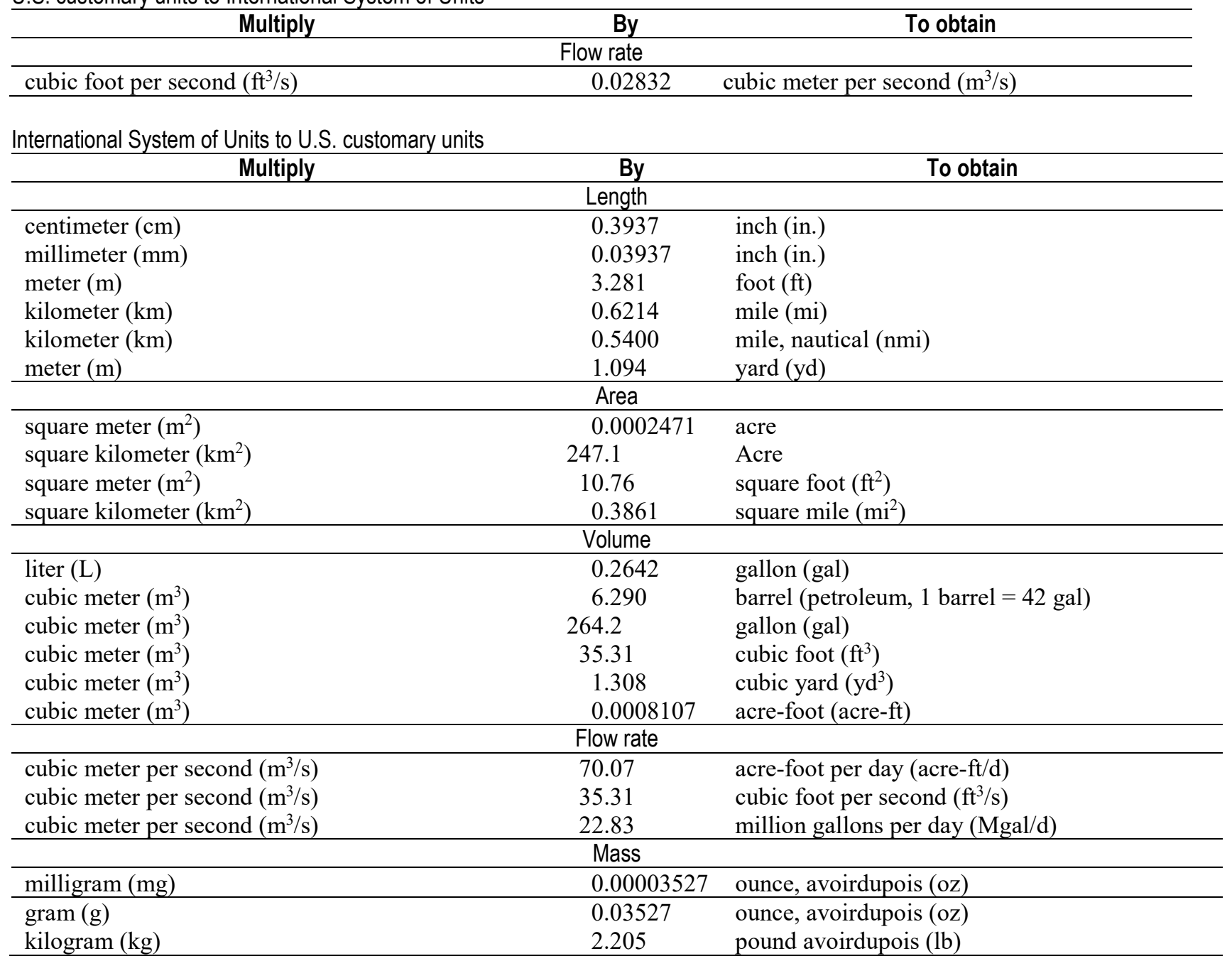

Temperature in degrees Celsius $\left({ }^{\circ} \mathrm{C}\right)$ may be converted to degrees Fahrenheit $\left({ }^{\circ} \mathrm{F}\right)$ as ${ }^{\circ} \mathrm{F}=\left(1.8 \times{ }^{\circ} \mathrm{C}\right)+32$.

\section{Datum}

Vertical coordinate information is referenced to the World Geodetic System of 1984 (WGS84).

Altitude, as used in this report, refers to distance above the vertical datum.

\section{Supplemental Information}

Concentrations of chemical constituents in water are given in milligrams per liter (mg/L). 
This page left intentionally blank 


\title{
Juvenile Salmonid Monitoring Following Removal of Condit Dam in the White Salmon River Watershed, Washington, 2017
}

By lan G. Jezorek, and Jill M. Hardiman

\begin{abstract}
Condit Dam, at river kilometer 5.3 on the White Salmon River, Washington, was breached in 2011, and removed completely in 2012, providing anadromous salmonids with the opportunity to recolonize habitat blocked for nearly 100 years. Prior to dam removal, a multiagency workgroup concluded that the preferred salmonid restoration alternative was to allow natural recolonization. Monitoring would assess fish recolonization efficacy, followed by management evaluation 5 years after dam removal. Limited monitoring of salmon and steelhead recolonization has occurred since 2011. The U.S. Geological Survey began juvenile salmonid monitoring in 2016 and did a second year during 2017, with sampling efforts like those of 2016. River conditions differed between the 2 years, both during (that is, high flows in 2017) and prior to (that is, 2015 summer drought conditions and December 2015 White Salmon River flood event) sampling. We operated a rotary screw trap at river kilometer 2.3 (3 kilometers downstream of the former dam site) from early April through early June to assess species diversity, and production of smolt and other migrant life stages. We also used backpack electrofishing during summer to assess juvenile salmonid distribution and abundance. Both sampling methods provided the opportunity to collect genetic samples (analysis of samples was not covered under funding received from the Mid-Columbia Fisheries Enhancement Group for the 2017 monitoring efforts) and to tag fish with passive integrated transponder (PIT) tags, which will provide life-history data through future recaptures and detections.

The screw trap captured steelhead (anadromous rainbow trout, Oncorhynchus mykiss), fry, parr, and smolts; coho salmon (O. kisutch) fry, parr, and smolts; and Chinook salmon $(O$. tshwaytscha) fry, parr, and one smolt. Prolonged high water and some missed trapping periods during 2017 prevented us from generating smolt estimates. Despite difficult trapping conditions, the number of coho salmon fry and parr, and steelhead fry and parr captured in 2017 exceeded those captured during 2016. The number of age- 0 Chinook salmon captured in the screw trap during 2017 was much higher $(n=222)$ than in $2016(n=4)$.
\end{abstract}


Electrofishing in tributaries provided information on distribution and abundance of juvenile coho salmon and $O$. mykiss. Juvenile coho salmon were again found in Mill and Buck Creeks and, for the first time, in Rattlesnake Creek (all three creeks are upstream of the former dam site). In both Rattlesnake and Buck Creeks, age-0 O. mykiss abundance decreased between 2016 and 2017; however, age- 1 and older $O$. mykiss and age- 0 coho salmon abundance increased between years at both sites. Data on O. mykiss abundance at sites in Buck and Rattlesnake Creeks is providing the opportunity to begin to understand trends and variability post-dam removal and to compare to pre-dam removal periods.

Mean age-0 O. mykiss abundance (fish per meter [fish $/ \mathrm{m}]$ ) at the Rattlesnake Creek site has been slightly lower during post-dam removal (mean $=3.0, \mathrm{n}=2$, range $=2.4-3.6$ ) than predam removal (mean $=3.4, \mathrm{n}=5$, range $=1.5-5.1)$. However, the presence of juvenile coho salmon in Rattlesnake Creek during $2017(0.5 \mathrm{fish} / \mathrm{m})$ brought total age-0 salmonid abundance in 2017 to $2.9 \mathrm{fish} / \mathrm{m}$. Mean age-1 or older O. mykiss abundance (fish/m) at the Rattlesnake Creek site has been lower post-dam removal (mean $=0.2, \mathrm{n}=2$, range $=0.1-0.3)$ than pre-dam removal $($ mean $=0.5, \mathrm{n}=2$, range $=0.3-0.8)$. Mean age-0 O. mykiss abundance (fish $/ \mathrm{m})$ at the Buck Creek site has been higher post-dam removal (mean $=2.1, \mathrm{n}=2$, range $=1.2-3.0)$ than pre-dam removal (mean $=1.8, \mathrm{n}=2$, range $=1.6-1.9)$. The addition of age- 0 coho salmon to Buck Creek brings mean age- 0 salmonid abundance post-dam removal to $2.7 \mathrm{fish} / \mathrm{m}$ (range $=1.9-3.4$ ). Mean age-1 or older $O$. mykiss abundance (fish $/ \mathrm{m}$ ) in Buck Creek has been slightly higher post-dam removal $($ mean $=0.8, \mathrm{n}=2$, range $=0.6-1.1)$ than pre-dam removal (mean $=0.6, \mathrm{n}=2$, both years 0.6).

\section{Introduction}

Condit Dam blocked anadromous fish passage for nearly 100 years on Washington's White Salmon River, a tributary of the Columbia River. The dam, at river kilometer (rkm) 5.3, was breached in 2011 and completely removed by September 14, 2012. Currently (2017), the river is in a state of flux, with riparian revegetation occurring in the former reservoir reach, and the continuation of sediment and gravel redistributing between the former dam site and the confluence with the Columbia River (Wilcox and others, 2014; Hatten and others, 2016). Anadromous fish have been using both reopened habitat upstream of the dam site and improved habitat downstream.

The White Salmon River historically supported steelhead (anadromous rainbow trout, Oncorhynchus mykiss), spring and fall Chinook salmon (O.tshawytscha), coho salmon (O. kisutch), and chum salmon (O. keta) runs (Lane and Lane Associates, 1981; Cowan, 1999; National Marine Fisheries Service, 2013a, 2013b), and provided local Native Americans with important fishing areas (National Marine Fisheries Service, 2013b). Additionally, Pacific lamprey (Entosphenus tridentatus) were present prior to construction of Condit Dam (Jolley and others, 2018). Removal of Condit Dam has reopened much potential anadromous fish habitat. Reconnected potential habitat is estimated at $27 \mathrm{~km}$ for coho salmon, $15 \mathrm{~km}$ for spring Chinook salmon, $7 \mathrm{~km}$ for fall Chinook salmon, and $50 \mathrm{~km}$ for steelhead (Northwest Power and Conservation Council, 2004; National Marine Fisheries Service, 2013a, 2013b). Since dam removal, a strategy of natural recolonization has been in effect. This followed recommendations of the multi-agency White Salmon Technical Work Group (WSTWG; Jezorek and Hardiman, 2017) and the Endangered Species Act [ESA] Recovery Plan for the White Salmon River (National Marine Fisheries Service, 2013b). 
The White Salmon watershed is considered part of the Lower Columbia River (LCR) Evolutionary Significant Unit (ESU) salmon recovery domain and the Middle Columbia River (MCR) Distinct Population Segment (DPS) steelhead recovery domain. It is a part of Washington State's Water Resource Inventory Area (WRIA) 29b (Cowan, 1999; National Marine Fisheries Service, 2009; National Marine Fisheries Service, 2013b). Removal of Condit Dam opened passage for LCR Chinook salmon (both fall and spring runs), LCR coho salmon, and MCR steelhead, which are all listed as threatened under the ESA (National Marine Fisheries Service, 2009; National Marine Fisheries Service, 2013a, 2013b). The ESA Recovery Plan for the White Salmon River Watershed (National Marine Fisheries Service, 2013b) suggests that White Salmon River coho salmon may be functionally extinct and that spring Chinook salmon likely are extirpated. The Middle Columbia River Steelhead ESA Recovery Plan (National Marine Fisheries Service, 2009) considers White Salmon steelhead "functionally extirpated". However, recent monitoring efforts in the White Salmon watershed have documented that steelhead, coho salmon, and Chinook salmon are spawning and producing offspring upstream of the former Condit Dam site (Jeremy Wilson, Washington Department of Fish and Wildlife, written commun., 2016; Joe Zendt, Yakama Nation Fisheries, written commun., 2016; Jezorek and Hardiman, 2017). Reconnected upstream habitat and improved habitat downstream of the Condit Dam site of the White Salmon River comprise a significant habitat gain in the Gorge Strata of the LCR ESU and the East Cascades MPG of the MCR DPS (Hardiman and Allen, 2015; Hatten and others, 2016).

Key questions about recolonizing fish are-what is their source and abundance, what is their productivity, what are limiting factors by life stage, and are they producing enough viable offspring to support population persistence? Numerous Federal and State plans recommend that these questions on Viable Salmonid Population (VSP) parameters be addressed (McElhany and others, 2000; National Marine Fisheries Service, 2009; Lower Columbia Fish Recovery Board, 2010a, 2010b; National Marine Fisheries Service, 2013a, 2013b). Population viability criteria can include juvenile out-migrant productivity and trends, population diversity, and spatial structure. Data outlined in the ESA Recovery Plan for the White Salmon River watershed will provide managers with information specific to White Salmon River and Gorge strata populations and will contribute to the growing body of science focused on dam removal.

Dam removals have increased nationwide (O'Connor and others, 2015; Bellmore and others, 2017). Studies are needed to address their efficacy as a conservation strategy for anadromous salmonids (Quiñones and others, 2015). Dam removal often involves uncertainty and management concerns regarding the physical and biological consequences (Tullos and others, 2016). Many dam removals are not scientifically monitored for biological effects or are monitored for only a short duration (O'Connor and others, 2015; Brewitt, 2016; Bellmore and others, 2017; Foley and others, 2017). More and longer-duration dam removal response studies are required to develop predictive models to inform managers and the public about effects of dam removal (Gregory and others, 2002; Hart and others, 2002; Pess, 2009; Brewitt, 2016; Foley and others, 2017).

The removal of Condit Dam provides an opportunity to evaluate the efficacy of dam removal for fish restoration and conservation, and contributes to the science of dam removals. Condit Dam is a relatively unique case to date because it was a high dam $(38 \mathrm{~m})$ with a large amount of sediment that was quickly released (1.8 million $\mathrm{m}^{3}$; Wilcox and others, 2014; O'Connor and others, 2015; Hatten and others, 2016), and because natural salmonid recolonization is being allowed with no direct hatchery supplementation. Many dam removals 
occur with little to no pre-removal data (Bellmore and others, 2016; Foley and others, 2017), but in the White Salmon River, there were some pre-dam removal fish studies. During 2006-09, the U.S. Geological Survey (USGS) and U.S. Fish and Wildlife Service (FWS) assessed species composition and relative abundance of juvenile salmonids downstream of Condit Dam at rkm 1.5, using a rotary screw trap (Allen and Connolly, 2011). Additionally, tributary habitat and salmonid abundance data were collected in Buck and Rattlesnake Creeks (Allen and others, 2003a, 2003b; Allen, Connolly, Jezorek, Munz, and Charrier, 2006; Allen, Connolly, Munz, and Charrier, 2006; Allen and others, 2012). These existing pre-dam removal data offer a baseline for understanding changes in fish distribution, abundance, and genetics.

Limited fish monitoring has occurred in the White Salmon River since removal of Condit Dam. Chinook salmon spawning surveys were conducted by FWS during 2012 and have been conducted by the Washington Department of Fish and Wildlife (WDFW) since 2013 following VSP guidelines (McElhany and others, 2000; Crawford and Rumsey, 2011) to estimate adult abundance, distribution, and origin (Allen and others, 2016). Steelhead spawning surveys, conducted in tributaries by Yakama Nation since 2012, are providing spatial distribution data and an index of abundance (Allen and others, 2016; Joe Zendt, Yakama Nation Fisheries, written commun., 2017). Because of funding limitations and challenges of surveying adult steelhead (that is, prolonged spawning period, high flows, turbidity, iteroparity), an approach that includes juvenile abundance and life-history data is particularly useful towards assessing population status (Lower Columbia Fish Recovery Board, 2010a). Like steelhead sampling, adult coho salmon sampling in the White Salmon River has significant challenges and limitations. No assessment of adult coho salmon use of the White Salmon River has been conducted since dam removal. As with steelhead, a broad monitoring approach including juvenile abundance and life-history data will provide the most robust assessment of efficacy of natural recolonization. The WSTWG, a multi-agency (Federal, State, Tribal, and others) group, continues to meet to coordinate ongoing efforts in the White Salmon River watershed (Allen and others, 2016; Jezorek and Hardiman, 2017).

During 2017, USGS completed a second year of juvenile salmonid monitoring in the White Salmon River watershed following dam removal. Project funding was received from the Mid-Columbia Fisheries Enhancement Group (MCFEG), which provided fiscal sponsorship for grants from the Washington State Salmon Recovery Funding Board and Clark-Skamania Flyfishers. Our goals were to assess smolt production from upstream of rkm 2.3, juvenile salmonid distribution in the watershed, and juvenile salmonid abundance at sites in Buck and Rattlesnake Creeks. These data will help evaluate dam removal as a restoration and conservation strategy, assess the efficacy of a natural recolonization strategy for anadromous salmonids, and inform managers of the status of ESA-listed salmonid stocks. Additionally, we collected genetic samples and passive integrated transponder- (PIT-) tagged fish. Though funding for genetic analysis was not part of our project, we are working with partners in the WSTWG to analyze these samples. Future recaptures and detections of PIT-tagged fish will contribute to knowledge of life-history diversity of naturally produced salmonids in the White Salmon River watershed. In this document, we refer to $O$. mykiss captured at the screw trap as steelhead since they are actively migrating, but because we do not know the migratory status of $O$. mykiss captured in electrofishing surveys, we simply refer to them as $O$. mykiss or steelhead/rainbow trout. 


\section{Description of Study Site}

The White Salmon River watershed encompasses about $1,000 \mathrm{~km}^{2}$ of Klickitat, Yakima, and Skamania Counties in south-central Washington (Haring, 2003). The White Salmon River is a tributary of the Columbia River at rkm 270 (fig. 1). The topography of the area includes mountainous terrain, deeply incised canyons, rolling hills, and low-gradient valley floors (Northwest Power and Conservation Council, 2004; National Marine Fisheries Service, 2013b). The White Salmon River is in the transitional eco-tone between the moderate coastal maritime climate zone and the continental inland climate zone. The climate is temperate, and around 80 percent of the annual precipitation occurs between October and March. Precipitation primarily is rain in the lower watershed and rain or snow in the higher altitudes, and ranges from $100 \mathrm{~cm}$ in the east to $240 \mathrm{~cm}$ in the north and west (Northwest Power and Conservation Council, 2004).

The White Salmon River has good water quantity and quality (Haring, 2003; Northwest Power and Conservation Council, 2004; Allen and Connolly, 2005). Discharge varies from a daily mean of about $19 \mathrm{~m}^{3} / \mathrm{s}$ during fall to about $44 \mathrm{~m}^{3} / \mathrm{s}$ in spring (U.S. Geological Survey, streamgage 14123500 [White Salmon River near Underwood, Washington]; Haring, 2003), and is maintained by snowmelt-fed springs and seeps throughout the summer (Haring, 2003; Northwest Power and Conservation Council, 2004; Allen and Connolly, 2005). Water temperatures in the river remain cold throughout the year, with maximum and minimum temperatures and dissolved oxygen levels within optimal levels for salmonids. Much of the White Salmon River is in a narrow, naturally incised bedrock and boulder canyon (Northwest Power and Conservation Council, 2004; Plummer and Zuckerman, 2012).

Numerous waterfalls are present on the White Salmon River. The largest waterfall is Big Brother Falls (about $7.3 \mathrm{~m}$ high) at rkm 26, which likely is the upstream extent of anadromous distribution (some anecdotal reports mention steelhead upstream of these falls, but are unconfirmed). BZ Falls (about $4.5 \mathrm{~m}$ high) is at rkm 20, and likely is a barrier to salmon, although steelhead most likely can ascend it (Reiser and others, 2006). Husum Falls (about $3 \mathrm{~m}$ high), at rkm 12.2, is a likely barrier to some salmon, although spring Chinook salmon and their redds have been found upstream of it (Allen and others, 2016; Jeremy Wilson, Washington Department of Fish and Wildlife, written commun., 2016).

The characteristics of the lower $8.0 \mathrm{~km}$ of the White Salmon River have rapidly changed since the 2011 breaching of Condit Dam and subsequent sediment release. An estimated 1.8 million $\mathrm{m}^{3}$ of sediments were impounded in the reservoir (Wilcox and others, 2014). This influx of sediment to the lower river has increased potential salmonid spawning and rearing habitat (Hardiman and Allen, 2015; Hatten and others, 2016). Natural watershed processes delivering large woody debris, cobbles, and gravel to the lower reaches have been restored (Wilcox and others, 2014; Hardiman and Allen, 2015; Allen and others, 2016; Hatten and others, 2016). The lower river likely will be in flux for the next few years as the river channel continues to stabilize and the riparian corridor re-establishes.

Four tributaries to the White Salmon River in our study area had anadromous fish access. Mill, Buck, Spring, and Rattlesnake Creeks all enter the White Salmon River between the former dam site and Husum Falls. During 2017, we sampled fish in Mill, Buck, and Rattlesnake creeks, but did not have permission to access Spring Creek.

Mill Creek flows to the White Salmon River from the west at rkm 6.4 (fig. 1). The Mill Creek basin is $11 \mathrm{~km}^{2}$, with a mix of private and Washington State owned lands. Altitude at the confluence with the White Salmon River is about $90 \mathrm{~m}$, with the upper headwaters at about 800 $\mathrm{m}$. The basin is steep and heavily forested. Plummer and Zuckerman (2012) reported many 
springs contributing flow to Mill Creek, which maintain low water temperatures. The estimates of potential anadromous fish habitat in Mill Creek range from 3.2 to $7 \mathrm{~km}$ (Northwest Power and Conservation Council, 2004; Plummer and Zuckerman, 2012).

Buck Creek flows into the White Salmon River from the northwest at rkm 7.5 (fig. 1). The Buck Creek basin is steep, mountainous terrain. The area of the basin is $36 \mathrm{~km}^{2}$, about 90 percent of which is owned by Washington Department of Natural Resources. Altitude in the basin ranges from $92 \mathrm{~m}$ at its mouth to $1,219 \mathrm{~m}$ at its headwaters. The basin is characterized by forested (second growth and early successional mixed conifer and deciduous), steep canyons with an incised basalt bedrock channel. Buck Creek also supplies domestic water to the city of White Salmon, Washington.

Allen and others (2012) defined four reaches in the part of Buck Creek accessible to anadromous fish, beginning at the confluence with the White Salmon River and extending upstream $6.4 \mathrm{~km}$, where there is a 6-m waterfall (the likely end of anadromy and immediately downstream of the City of White Salmon municipal water facility). Allen and others (2012) reported that most of the habitat in Buck Creek was large cobble riffles. Boulders and cobbles were the dominant substrate; spawning gravel was limited. They reported smaller and less frequent instream large woody debris (LWD) than found in unmanaged basins of similar size and character. Minimum discharge in Buck Creek was reported by Allen and others (2012) as 0.02 $\mathrm{m}^{3} / \mathrm{s}$ at the mouth, and $0.009 \mathrm{~m}^{3} / \mathrm{s}$ downstream of the water diversion at $\mathrm{rkm} 3.1$. Water temperatures in Buck Creek are favorable to salmonids. Temperatures at the lower end of Buck Creek only occasionally exceeded $16^{\circ} \mathrm{C}$, and never exceeded $18{ }^{\circ} \mathrm{C}$ during 2009,2010 , and 2016 (Allen and others, 2012; Jezorek and Hardiman, 2017).

Rattlesnake Creek flows to the White Salmon River from the east at rkm 13.8 (fig. 1). The Rattlesnake Creek basin covers $143 \mathrm{~km}^{2}$, and nearly all is privately owned in a mix of forest and some agricultural lands. Altitude is about $114 \mathrm{~m}$ at the mouth to $927 \mathrm{~m}$ at ridge tops at the basin's eastern edge. There are two notable sets of waterfalls in Rattlesnake Creek. The lower set of falls, at rkm 2.4, has three individual drops, with the middle one being the largest (about $3.6 \mathrm{~m}$ total height, but with a step and 1.5 -m-deep pocket at $2.1 \mathrm{~m}$ ). The lower falls likely are a barrier to resident fish, but may be passable to some anadromous fish. An adult steelhead was sighted upstream of these falls during 2016 (Joe Zendt, Yakama Nation Fisheries, written. commun., 2016). The upper falls, at rkm 17, has two separate drops of about 22-25 $\mathrm{m}$ each and is a fish barrier. Allen, Connolly, Jezorek, Munz, and Charrier (2006) reported that habitat conditions in all reaches of Rattlesnake Creek were poor. Pool frequency and quality were low. Counts of LWD were low and riparian condition was degraded (Allen, Connolly, Jezorek, Munz, and Charrier, 2006; Plummer and Zuckerman, 2012). Discharge in Rattlesnake Creek is extremely low during summer (Northwest Power and Conservation Council, 2004; Allen and Connolly, 2005; Allen, Connolly, Jezorek, Munz, and Charrier, 2006; Allen, Connolly, Munz, and Charrier, 2006; Plummer and Zuckerman, 2012). Discharge near the mouth of Rattlesnake Creek can be less than $0.0018 \mathrm{~m}^{3} / \mathrm{s}$ and surface flow in riffles is barely discernible in some reaches. Water temperature in Rattlesnake Creek can approach lethal limits for salmonids. Allen, Connolly, Jezorek, Munz, and Charrier (2006) reported a maximum temperature of $23.6^{\circ} \mathrm{C}$ at rkm 0.9 , and temperatures that exceeded $20^{\circ} \mathrm{C}$ throughout the drainage were common. During 2016, water temperature at the mouth of Rattlesnake Creek exceeded $16{ }^{\circ} \mathrm{C}$ every day during July and August, with a maximum of $22.8^{\circ} \mathrm{C}$ (Jezorek and Hardiman, 2017). 


\section{Study Methods}

\section{Smolt Trapping}

We operated a 1.5-m rotary screw trap (E.G. Solutions, Corvallis, Oregon) at rkm 2.3 of the White Salmon River (fig. 1; table 1). This was the first site upstream of the confluence with the Columbia River where channel characteristics and access enabled trapping. We fished the trap intermittently (because of high-flow conditions) from early April to mid-June 2017. Methods following those outlined in Volkhardt and others (2007).

Each day, debris was removed from the live box, and captured fish were netted into buckets for transport to shore. Captured fish were held in buckets or coolers with ambient aerated stream water. Fish were anesthetized with $50 \mathrm{mg} / \mathrm{L}$ tricaine methanesulfonate (MS-222), identified to species, measured for fork length (FL) to the nearest millimeter, weighed to the nearest $0.1 \mathrm{~g}$, and classified by life stage (fry, parr, smolt). Fin tissue was taken from some Chinook salmon, steelhead, coho salmon, and lamprey, and archived for genetic analysis. Salmonids were checked for PIT tags or dye marks to determine if they were recaptures. Fish 60$\mathrm{mm}$ or greater FL were scanned for PIT tags and PIT-tagged if not previously tagged. Fish from 60- to 69-mm FL were tagged with 9-mm tags, and fish greater than 69-mm FL were tagged with 12 -mm tags; both tag sizes were $134.2 \mathrm{kHz}$, and all were full duplex. Tags were injected into the peritoneal cavity following methods outlined by Columbia Basin Fish and Wildlife Authority (2014). Salmonids less than 60-mm FL were batch marked with Bismark Brown Y biological stain $(16 \mathrm{mg} / \mathrm{L}$; Sigma Chemical Company, St. Louis Missouri).

We marked fish to calculate migrant estimates following standard methods (Thedinga and others, 1994; Volkhardt and others, 2007). Each day, newly marked fish (PIT-tagged, fin clipped, or batch dye-marked) were transported by vehicle to an access point at the PacifiCorp Powerhouse at $\mathrm{rkm} 3.0$, where they were released. Recaptured fish were released downstream of the trap.

All screw-trap data were electronically entered on a field computer provided by WDFW, and were configured to accept data in their Juvenile Migrant Exchange (JMX) database. All screw-trap data from 2017 were entered in the JMX database. All mark and recapture data from PIT-tagged fish were submitted to the PTAGIS database administered by Pacific States Marine Fisheries Commission.

\section{Electrofishing}

We used backpack electrofishing to assess juvenile salmonid abundance in the most downstream reach of Rattlesnake Creek (start at rkm 0.2; site length, $223 \mathrm{~m}$ ) and a section of Buck Creek (start at rkm 2.0; site length, $230 \mathrm{~m}$; fig. 1). Additionally, we backpack electrofished for fish distribution and species assemblage in a new section of Mill Creek at about rkm 1.3. The Mill Creek 2018 sample section was about $250 \mathrm{~m}$ long and was about $0.7 \mathrm{~km}$ upstream of our uppermost sampling in Mill Creek in 2016, which was to rkm 0.6. 
We estimated abundance of fish using the mark-recapture methods outlined in Temple and Pearsons (2007). We block netted the stream at the upstream and downstream ends to prevent emigration or immigration. We used two block nets at each end of the sample section, one of which (of coarser mesh) was placed upstream of the other to collect material brought down by the current and to ensure that the lower net was not knocked down by debris. The net lead lines were secured snugly to the streambed with boulders and large cobble, and the upper net line was tied off so that it was at least $0.5 \mathrm{~m}$ above the water surface.

Once the nets were secured, we electrofished the section and marked fish with either PIT tags or fin clips. Three crew members dipnetted fish and placed them in buckets or coolers with ambient, aerated stream water. We anesthetized captured fish with the lightest possible dose of MS-222, measured FL to the nearest millimeter, weighed to the nearest $0.1 \mathrm{~g}$, and marked. Salmonids with a 70-mm or greater FL were PIT-tagged with a 12-mm tag, and salmonids with a 55-69-mm FL were PIT-tagged with a 9-mm tag (both tags were $134.2 \mathrm{kHz}$ ). Smaller fish were given a caudal fin clip. Fish were released as close as possible to their point of capture. Block nets were left overnight, and the following day we repeated the electrofishing effort. During fish workup for the recapture pass, all fish were checked for a PIT tag or fin clip mark.

For mark-recapture analysis, we followed methods outlined in Temple and Pearsons (2007). We used length-frequency histograms to assign ages to age- 0 and age- 1 or older fish (appendix figs. 1.1-1.5). We estimated the abundance of fish and associated variance, by species and age class (age-0 and age-1 and older) in study reaches using Chapman's modification of the Peterson estimate (Chapman, 1951), as follows:

$$
\begin{gathered}
\hat{N}=\left[\frac{(M+1)(C+1)}{(R+1)}\right]-1, \text { and } \\
V(\hat{N})=\frac{\left(\hat{N}^{2}\right)(C-R)}{(C+1)(R+2)},
\end{gathered}
$$

where

$$
\begin{aligned}
& \hat{N}=\text { population estimate } \\
& M=\text { number of fish marked during the mark sample effort } \\
& C=\text { total number of fish captured in the recapture sample effort } \\
& R=\text { number of marked fish captured in the recapture sample effort, and } \\
& V=\text { variance. }
\end{aligned}
$$

To quantify habitat area, we measured width and depth at 10 transects, equally spaced through the mark-recapture section. With these data, we calculated the area of the section and could estimate fish per meter and fish per square meter. 


\section{Results}

\section{Smolt Trapping Results}

We captured steelhead, coho salmon, and Chinook salmon in the screw trap during operational periods from April $10^{1}$ to June 12, 2017 (figs. 2-4; table 2). The trap was fished for 45 days during this period. Because of high-flow conditions (greater than 2,400 $\mathrm{ft}^{3} / \mathrm{s}$, with a peak in late March at about 3,800 $\mathrm{ft}^{3} / \mathrm{s}$; USGS streamgage 14123500 [White Salmon River near Underwood, Washington]; https://waterdata.usgs.gov/nwis/uv?site_no=14123500), sampling days were limited and the trap frequently was fished outside the thalweg to prevent damage. The trap was not operated during April 15-17, April 25-28, and May 5-13. Chinook salmon were the most abundant species captured, with 203 fry, 19 parr, and 1 smolt. Steelhead were the next most abundant species captured, with 14 fry, 61 parr, and 40 smolts. Coho salmon captured were, 59 fry, 21 parr, and 13 smolts (table 2).

We could not calculate migrant abundance estimates at the screw trap in 2017 because of the low catch rate (table 3 ), and missed sampling days due to high water. Of the 40 steelhead smolts captured, 39 were PIT-tagged, and 1 was recaptured. No coho salmon smolts were recaptured of the 12 PIT-tagged. Most of the fish captured were age- 0 Chinook salmon $(n=222$; table 2). We dye-marked 192 age-0 Chinook salmon and recaptured 4 of them (table 3 ).

All salmonid species were captured throughout the sample period, but timing of the life stages of individual species differed. Steelhead parr and smolts were captured throughout the sample period, but no fry were captured until May 17 (fig. 2). Daily catch of steelhead smolt peaked on April 22. Coho salmon fry were captured throughout the sampling period, but catch rate increased in late May (fig. 3). Coho salmon parr were primarily captured during late May and into June. Chinook salmon fry were captured throughout the sample period, but the peak daily catches occurred in the latter one-half of May (fig. 4). Chinook salmon parr were captured from April 24 to May 21. One Chinook salmon smolt was captured on May 26 and is the first known documentation of a Chinook salmon smolt from this site.

We also captured 19 lamprey, which could be either Pacific lamprey (Entosphenus tridentatus) or Brook lamprey (Lampetra richardsoni). These were not identified to species in the field. Fin clips for genetic analysis were obtained for all but two of the lamprey captured at the screw trap.

There were some notable differences in the smolt trap monitoring and results in 2016 and 2017. During 2016, the trap was fished for 62 days, whereas during 2017, it was fished for 45 days. Despite fewer sampling days, the number of fry and parr captured was greater in 2017 than in 2016 for all species (table 2), with the greatest difference being in Chinook salmon fry (2016, $n=4 ; 2017, n=203)$. However, fewer steelhead and coho salmon smolts were captured in 2017 than in 2016 (table 2).

\footnotetext{
${ }^{1}$ We began fishing the trap on April 10. April 11 was the first day the trap was checked and fish were handled, as indicated in figures $2-4$ and table 2 .
} 
Pre-dam removal screw trapping in the White Salmon River (2007-09) provides an opportunity for comparison with the post-Condit Dam removal screw trapping (2016-17; fig. 5). The screw trap was located at rkm 1.5 prior to dam removal and at rkm 2.3 after dam removal. Catch-per-day of age- 1 or older steelhead at the screw trap increased considerably since dam removal, whereas catch-per-day of age-0 steelhead slightly decreased. Catch-per-day of age-1 coho salmon at the screw trap increased since dam removal, although catch-per-day of age- 0 coho salmon decreased. Age-0 Chinook salmon catch-per-day was much less in the post-dam removal years than in the pre-dam removal years. However, much of Chinook salmon spawning occurs downstream of the current smolt trap site at rkm 2.3 .

\section{Electrofishing Results}

We backpack electrofished in Mill, Buck, and Rattlesnake Creeks (table 1). We found $O$. mykiss, coho salmon, and cutthroat trout present at all three sites. We did not detect Chinook salmon at any electrofishing sites (table 4 ). We estimated abundance of age- 0 and age- 1 and older salmonids in sections of Rattlesnake and Buck Creeks (figs. 6 and 7; table 5); both sites had been sampled prior to removal of Condit Dam. Abundance of age-0 O. mykiss during 2017 was $2.4 \mathrm{fish} / \mathrm{m}$ (standard error $[\mathrm{SE}]=0.23$ ) at the Rattlesnake Creek site and $1.2 \mathrm{fish} / \mathrm{m}(\mathrm{SE}=$ $0.27)$ at the Buck Creek site. Abundance of age- 1 and older $O$. mykiss was $0.3 \mathrm{fish} / \mathrm{m}(\mathrm{SE}=0.03)$ at the Rattlesnake Creek site, and was $1.1 \mathrm{fish} / \mathrm{m}(\mathrm{SE}=0.11)$ at the Buck Creek site. In both Rattlesnake and Buck Creeks, age-0 O. mykiss abundance decreased between 2016 and 2017 while the age-1 and older $O$. mykiss and coho salmon abundance increased (figs. 6 and 7). Coho salmon were found at the Rattlesnake Creek site for the first time in 2017, with an abundance of $0.5 \mathrm{fish} / \mathrm{m}(\mathrm{SE}=0.08)$. Abundance of age-0 coho salmon at the Buck Creek site during 2017 was $0.7 \mathrm{fish} / \mathrm{m}(\mathrm{SE}=0.08)$.

Mean age-0 O. mykiss abundance (fish/m) at the Rattlesnake Creek site has been slightly lower post-dam removal (mean $=3.0, \mathrm{n}=2$, range $=2.4-3.6)$ than pre-dam removal (mean $=3.4$, $\mathrm{n}=5$, range $=1.5-5.1$; fig. 6). However, the presence of juvenile coho salmon in Rattlesnake Creek during 2017 (0.5 fish $/ \mathrm{m})$ brought total age-0 salmonid abundance in 2017 to $2.9 \mathrm{fish} / \mathrm{m}$. Mean age-1 or older $O$. mykiss abundance (fish/m) at the Rattlesnake Creek site has been lower post-dam removal (mean $=0.2, \mathrm{n}=2$, range $=0.1-0.3)$ than pre-dam removal (mean $=0.5, \mathrm{n}=2$, range $=0.3-0.8$; fig. 6). Mean age-0 O. mykiss abundance $($ fish $/ \mathrm{m})$ at the Buck Creek site has been higher post-dam removal (mean $=2.1, \mathrm{n}=2$, range $=1.2-3.0)$ than pre-dam removal (mean $=1.8, \mathrm{n}=2$, range $=1.6-1.9$; fig. 7). The addition of age- 0 coho salmon to Buck Creek brings mean age- 0 salmonid abundance to $2.7 \mathrm{fish} / \mathrm{m}$ post-dam removal (range $=1.9-3.4$ ). Mean age-1 or older O. mykiss abundance (fish $/ \mathrm{m}$ ) in Buck Creek has been slightly higher post-dam removal $($ mean $=0.8, \mathrm{n}=2$, range $=0.6-1.1)$ than pre-dam removal $($ mean $=0.6, \mathrm{n}=2$, both years 0.6$)$. In Mill Creek, we sampled at rkm 1.3 for species composition and found coho salmon, cutthroat trout (O. clarkii), and O. mykiss (table 4). This is the most upstream sampling and documentation of Coho Salmon in Mill Creek since Condit Dam removal. Cutthroat Trout were the most common species found at this location, and most were age-1 and older (appendix fig. 1.5). 


\section{Additional Passive Integrated Transponder-Tagging Data}

We PIT-tagged salmonids captured by screw trapping and electrofishing, during 2016 and 2017. Although the primary purpose of tagging is for mark-recapture estimates, additional data are possible through re-contacts of PIT-tagged fish both in the White Salmon watershed and at sites in the Columbia River. We are compiling these recapture and detection data. During 2017, we recaptured 16 steelhead in Buck Creek and 7 in Rattlesnake Creek that were PITtagged in 2016. Twenty-one coho salmon and 34 steelhead that were PIT-tagged at the screw trap in 2016 were detected at juvenile detection sites in the Columbia River (Bonneville Dam, estuary trawl, bird colonies) during spring 2016. Two coho salmon PIT-tagged in Buck Creek and one steelhead PIT-tagged in Mill Creek during 2016 were recorded at juvenile detection sites in the Columbia River during 2017.

Two coho salmon and one steelhead PIT-tagged at the screw trap in 2016 were detected at Bonneville Dam as adults in 2017. The two coho salmon were detected on September 28 and October 22, and the steelhead were detected on August 11. The steelhead was subsequently detected at The Dalles Dam on September 26.

\section{Discussion}

During 2017, we continued to monitor juvenile salmonids for a second year in the White Salmon River following the removal of Condit Dam. These efforts have documented naturally spawned steelhead and coho salmon smolts, and Chinook salmon fry originating upstream of rkm 2.3. We again found juvenile coho salmon in Mill and Buck Creeks. In Mill Creek in 2017, we sampled farther upstream than in 2016 and found juvenile coho salmon. The range distribution of juvenile coho salmon expanded, with detection in Rattlesnake Creek for the first time since dam removal.

Smolt trapping continued to be feasible at rkm 2.3, but high flows during 2017 made sampling difficult, with fewer operational days and low trap efficiency. The median daily flows for the last 97 years were around $1,500 \mathrm{ft}^{3} / \mathrm{s}$ during mid-March to mid-June. In 2017, flows in mid-March were either near or greater than $3,000 \mathrm{ft}^{3} / \mathrm{s}$, and were greater than $2,000 \mathrm{ft}^{3} / \mathrm{s}$ for the entire sampling period (USGS streamgage 14123500, White Salmon River near Underwood, Washington). Some sample days were missed because of high flow, and the trap was sometimes fished off the thalweg to avoid damage. Although recapture rates were similar to screw trapping recapture rates in nearby rivers of similar size (Buehrens and Cochran, 2016; Zendt and others, 2016), the number of fish captured/recaptured was low, which precluded estimating abundance.

Precision of smolt estimates could be improved by several methods to increase the number of fish captured or the trap efficiency (Jezorek and Hardiman, 2017). Further assessment of the trap location has resulted in a determination that a larger trap is unlikely to work at this site; however, an additional small trap is a possibility. Operation of other traps or weirs to collect and tag fish upstream of the main trap location could increase precision of estimates. These traps or weirs could be placed in the mainstem or in tributaries. Additional trapping and tagging would increase operating cost. 
The increase in Chinook salmon fry captured in the screw trapping during 2017 provides evidence of successful upstream spawning of Chinook salmon. A substantial flood occurred in the White Salmon River in December 2015 (estimated at a 25-year interval event). This flood, combined with the dynamic nature of much of the substrate in the river both upstream and downstream of the dam site, may have resulted in high egg-to-fry mortality due to bed scour and subsequent redd destruction during the previous egg incubation period. No such flood event occurred during fall 2016 or winter 2017.

Although Chinook salmon fry catch greatly increased from 2016 to 2017, we captured far fewer Chinook salmon fry in the screw trap than during pre-dam removal sampling. During the pre-dam removal period, the screw trap was located farther downstream (rkm 1.5), and most fall Chinook salmon spawning occurs between there and the current trap location ( $\mathrm{rkm} \mathrm{2.3).}$

However, fall Chinook salmon spawn upstream of rkm 2.3, as do most spring Chinook salmon (Jeremy Wilson, Washington Department of Fish and Wildlife, written commun., 2016). To date (2017), no assessment of Chinook salmon adult-to-juvenile recruitment has occurred in the White Salmon River. Continued monitoring will allow such relations to be explored. Genetic analysis will help assess the parental origin of juveniles captured at the trap.

The increase in catch-per-day of age- 1 or older steelhead and age-1 coho salmon at the screw trap compared to pre-dam removal trapping provides evidence of successful spawning and smolt out-migration from upstream of the trap site. This may be a result of increased anadromous spawning in the watershed, increased suitable rearing habitat for fry or parr, or an increase in anadromous life-history expression from $O$. mykiss in the watershed. The slightly lower catchper-day rates for age-0 steelhead and coho salmon may result from increased rearing opportunity upstream of the trap site. Because any steelhead or coho salmon that spawned in the White Salmon River prior to 2012 had to do so downstream of Condit Dam (rkm 5.3), age-0 habitat may have been limited, resulting in downstream displacement. Specifically, the reach of the White Salmon between Condit Dam and the Powerhouse at rkm 3.0 had varied and reduced flow during power generation, which may have displaced fish.

The detection of juvenile coho salmon in Mill Creek (to at least rkm 1.3), the increase in juvenile coho salmon abundance in Buck Creek (to at least rkm 2.2), and the detection of coho salmon in Rattlesnake Creek suggest increasing success of coho salmon spawning in the watershed. This could be a result of increased spawners or better instream conditions in 2017 than 2016. Increases in abundance of age-1 or older O. mykiss at our sites in Buck and Rattlesnake Creeks may be a result of increased spawning success or increased survival following challenging instream conditions during summer 2016, particularly in Rattlesnake Creek.

Detections of PIT-tagged coho salmon at Bonneville Dam that were tagged in Buck Creek in 2016 indicate successful smolting. Detections of two adult coho salmon and one adult steelhead at Bonneville Dam that were PIT-tagged at the screw trap in 2016 could be indicative of the beginning of natural recolonization and viability of naturally spawned juveniles. Coho salmon and steelhead spawning frequency and juvenile use of the White Salmon River are unknown. It is assumed that Husum Falls is a barrier to adult coho salmon, but further sampling is needed to assess coho salmon and steelhead distribution in the mainstem and tributaries. 
Currently (2017), the White Salmon River is still a dynamic environment following the removal of Condit Dam and redistribution of sediments. Events such as the dry summer of 2015, the flood of December 2015, and the sustained high flow of spring and summer 2017 can affect different life stages of different species and influence population variability independent of spawner levels. The many possible limiting factors by life stage, species, and cohort in the watershed cannot be addressed without long-term monitoring of both adults and juveniles. Longterm trend analysis is required to reach firm conclusions about efficacy of restoration (Kondolf and others, 2007; Brewitt, 2016). Studies of restoration projects that are of short duration could result in premature and erroneous conclusions (Herrick and others, 2006). Pess (2009) reported that as many as 20-25 years may be required to restore salmonid populations following dam removal, highlighting the need for long-term studies.

Adult anadromous fish are spawning in the areas of the White Salmon River watershed made accessible by the removal of Condit Dam. Much remains to be learned about the origin of these adults and their spawning success. Juvenile fish are being produced, but their parental origin and relation to listed stocks is unknown. The potential influence of hatchery-origin spawners on an attempt to naturally reestablish a sustainable wild population (Dammerman and others, 2016) is a management concern. This is especially true of fall Chinook salmon, with both Tule and Bright stocks spawning in the river with potential for interbreeding and redd superimposition.

The juvenile sampling methods used during 2016 and 2017 provided an opportunity to PIT tag fish and archive genetics samples. Genetic samples for $O$. mykiss captured in the watershed during 2016 are in the process of being analyzed to determine relatedness to resident stocks that were present upstream of the dam or to hatchery or wild steelhead potentially recolonizing the White Salmon River watershed. Biologists have theorized that the White Salmon River may support both summer and winter run steelhead (Interior Columbia Technical Recovery Team, 2008; National Marine Fisheries Service, 2013b). The nearby Hood River, Oregon, and Klickitat River, Washington, support both summer and winter run steelhead. If the White Salmon River supports both summer and winter run steelhead, genetic analysis would be desirable to determine relatedness to local runs, which are assigned to different DPSs. The Hood River steelhead are considered part of the Lower Columbia River DPS, and the Klickitat River steelhead are considered part of the Middle Columbia DPS. The White Salmon steelhead are considered part of the Middle Columbia River DPS (Chinook and coho salmon in the White Salmon River are considered part of the Lower Columbia River ESU).

We hope that the juvenile salmonid data collected in the White Salmon River watershed during 2016 and 2017 can be a starting point for a longer-term monitoring program in concert with other efforts by the WSTWG. These data can be of use in establishing some spawner/smolt relations and providing a basis for assessing changes in distribution and spawning success as fisheries trend data are gathered following this major dam removal. These data also will provide managers with information on VSP parameters needed to evaluate health of stocks of ESA listed fish. The descriptive data collected from juvenile and adult salmonids in the White Salmon watershed will help managers evaluate dam removal efficacy, the natural recolonization strategy, and the contribution of anadromous fish in the White Salmon River watershed to strengthening abundance and diversity of ESA listed populations. 


\section{Acknowledgments}

We thank Margaret Neuman, Mid-Columbia Fisheries Enhancement Group (MCFEG), for her support and tireless efforts to acquire and administer funding for this project. We thank our fellow U.S. Geological Survey employees Shane Amen, Brad Liedtke, Rachel Ohnemus, Dennis Sitherwood, and Andy Wells, who provided many hours of help in the field and office. Seth Raehsler, with MCFEG, also provided field assistance. We also thank the U.S. Geological Survey Science in Support of Native American Relations program and the National Association of Geoscience Teachers program which provided support for seasonal staff. Jacob Anderson, with Klickitat County, provided support and communication assistance during the proposal process. Thomas Beuhrens and Bryce Glaser of WDFW provided support and feedback for our proposal. Additionally, they provided a tablet field computer for use at our smolt trap site, which saved many hours of manual data entry. Ben Warren and Daniel Warren, with the Washington Department of Fish and Wildlife, provided us with instruction in using the tablet computer. Larry Zeigenfuss, Joe Skalicky, and Mark Doulos, with the U.S. Fish and Wildlife Service (FWS), provided us with permission to access FWS property and provided help with deployment and removal of the smolt trap. Joe Zendt and Mike Babcock, with the Yakama Nation Fisheries Program, provided us with passive integrated transponder tags. We would like to thank the landowners who provided access to their property, including PacificCorp, the U.S. Forest Service, the Washington State Department of Natural Resources, Steve Stampfli, and Terie Tietjen. We would also like to thank the technical and citizens committees of the Klickitat Lead Entity and the staff and board of the Lower Columbia Fish Recovery Board for their support. 


\section{References Cited}

Allen, M.B., and Connolly, P.J., 2005, Assessment of the White Salmon watershed using the ecosystem diagnosis and treatment model-Final Report for the period November 2003 to December 2004: Yakama Nation, Agreement No. BGC045042, 55 p.

Allen, M.B., and Connolly, P.J., 2011, Composition and relative abundance of fish species in the lower White Salmon River, Washington, prior to the removal of Condit Dam: U.S. Geological Survey Open-File Report 2011-1087, 32 p.

Allen, M.B., Connolly, P.J., Jezorek, I.G., Munz, C., and Charrier, J.C., 2006, Assess current and potential salmonid production in Rattlesnake Creek in association with restoration efforts: U.S. Geological Survey 2004-2005 Annual Report, Project No. 200102500, BPA Report DOE/BP00005068-4, 101 p., accessed November 28, 2016. at https://www.cbfish.org/Document.mvc/Viewer/00005068-4.

Allen, M.B., Connolly, P.J., and Martens, K., 2003a, Report A-Characterization of flow, temperature, habitat conditions, and fish populations in the Rattlesnake Creek watershed, in Connolly, P.J., ed., Assess current and potential salmonid production in Rattlesnake Creek associated with restoration efforts: U.S. Geological Survey 2001 Annual Report for Bonneville Power Administration, Project No. 200102500, 65 p., accessed November 28, 2016, at https://www.cbfish.org/Document.mvc/Viewer/00005068-1.

Allen, M.B., Connolly, P.J., and Martens, K., 2003b, Report A-Characterization of flow, temperature, habitat conditions, and fish populations in the Rattlesnake Creek watershed, in Connolly, P.J., ed.., Assess current and potential salmonid production in Rattlesnake Creek associated with restoration efforts: U.S. Geological Survey 2002 Annual Report for Bonneville Power Administration, Project No. 200102500, 188 p., accessed November 28, 2016, at https://www.cbfish.org/Document.mvc/Viewer/00005068-2.

Allen, M.B., Connolly, P.J., Munz, C.S., and Charrier, J.C., 2006, Assess current and potential salmonid production in Rattlesnake Creek in association with restoration efforts: U.S. Geological Survey 2003 Annual Report for Bonneville Power Administration, Project No. 200102500, 128 p., accessed November 28, 2016, at https://www.cbfish.org/Document.mvc/Viewer/00005068-3.

Allen, M.B., Engle, R.O., Zendt, J.S., Shrier, F.C., Wilson, J.T., and Connolly, P.J., 2016, Salmon and steelhead in the White Salmon River after the removal of Condit Dam-Planning efforts and recolonization results: Fisheries, v. 41, p. 190-203.

Allen, M.B., Munz, C., Burkhardt, J., and Connolly, P.J., 2012, Fish Population and habitat analysis in Buck Creek, Washington, prior to recolonization by anadromous salmonids after the removal of Condit Dam: U.S. Geological Survey Open-File Report 2012-1270, 38 p.

Bellmore, J.R., Duda, J.J., Craig, L.S., Greene, S.L., Torgersen, C.E., Collins, M.J., and Vittum, K., 2017, Status and trends of dam removal research in the United States: WIREs Water 2017, v. 4, p. e1164, doi:10.1002/wat2.1164.

Brewitt, P.K., 2016, Do the fish return?-A qualitative assessment of anadromous Pacific salmonids' upstream movement after dam removal: Northwest Science, v. 90, p. 433-449.

Buehrens, T., and Cochran, P., 2016, Abundance and productivity of Wind River steelhead and preliminary assessment of their response to Hemlock Dam removal, 2014: Washington Department of Fish and Wildlife Annual Report, Project Number 1998-019-00, BPA Report, accessed December 20, 2016, at https:/www.cbfish.org/Document.mvc/Viewer/P149707. 
Chapman, D.G., 1951, Some properties of hypergeometric distribution with applications to zoological sample censuses: University of California Publications in Statistics, v. 1, p. 131159.

Columbia Basin Fish and Wildlife Authority, 2014, PIT tag marking procedures manual: Portland, Oregon, PIT Tag Steering Committee, 34 p., accessed December 17, 2016, at www.ptagis.org/docs/defoult-source/ptagis-program-documents/2014-mark-proceduresmanual.pdf?sfvrsn=2.

Cowan, B., 1999, WRIA 29 salmonid habitat limiting factors analysis report: Olympia, Washington, Washington Conservation Commission, 98 p.

Crawford, B.A., and Rumsey, S.M., 2011, Guidance for monitoring recovery of Pacific Northwest salmon and steelhead listed under the Endangered Species Act: National Marine Fisheries Service, Northwest Region, Portland, Oregon, 160 p., accessed December 12, 2016, at,

http://www.westcoast.fisheries.noaa.gov/publications/recovery_planning/salmon_steelhead/do mains/rme-guidance.pdf.

Dammerman, K., Hand, D., Olson, D., Poirier, J., Pastor, S., and Rivera, J., 2016, Monitoring and evaluation updates for John Day / The Dalles Dam mitigation programs at Spring Creek and Little White Salmon National Fish Hatcheries-2016 annual report: U.S. Fish and Wildlife Service, Vancouver, Washington, accessed December 13, 2016, at https://www.fws.gov/columbiariver/publications/JDM\%20Report_USACE_Dammerman\%20e $\mathrm{t} \% 20 \mathrm{al} \% 200 \mathrm{ct} \% 202016$.pdf.

Foley, M.M., Magilligan, F.J., Torgerson, C.E., Major, J.J., Anderson, C.W., Connolly, P.J., Wieferich, D., Shafroth, P.B., Evans, J.E., Infante, D., and Craig, L.S., 2017, Landscape context and the biophysical response of rivers to dam removal in the United States: PLoS ONE, v. 12, no. 7, p. e0180107, https://doi.org/10.1371/journal.pone.0180107.

Gregory, S., Li, H., and Li, J., 2002, The conceptual basis for ecological responses to dam removal: BioScience, v. 52, p. 713-723.

Hardiman, J.M., and Allen, M.B., 2015, Salmon habitat assessment for conservation planning in the lower White Salmon River, Washington: U.S. Geological Survey Open-File Report 2015$1100,24 \mathrm{p}$.

Haring, D., 2003, Addendum to Wind/White Salmon WRIA 29 salmonid habitat limiting factor analysis (originally issued July 1999)_White Salmon River watershed: Washington Conservation Commission, $98 \mathrm{p}$.

Hart, D.D., Johnson, T.E., Bushaw-Newton, K.L., Horwithz, R.J., Benarek, A.T., Charles, D.F., Kreeger, D.A., and Velinsky, D.J., 2002, Dam removal—Challenges and opportunities for ecological research and river restoration: BioScience v. 52, p. 669-681.

Hatten, J.R., Batt, T.R., Skalicky, J.J., Engle, R. Barton, G.J., Fosness, R.L., and Warren, J., 2016, Effects of dam removal on tule fall Chinook salmon spawning habitat in the White Salmon River, Washington: River Research and Applications, v. 32, p. 1481-1492.

Herrick, J.E., Schuman, G.E., and Rango, A., 2006, Monitoring ecological processes for restoration projects: Journal for Nature Conservation, v. 14, p. 161-171.

Interior Columbia Technical Recovery Team, 2008, Middle Columbia River steelhead distinct population segment (DPS), volume 3 of Current status reviews-Interior Columbia Basin salmon and ESUs and steelhead DPSs: Interior Columbia Technical Recovery Team, 312 p. 
Jezorek, I.G., and Hardiman, J.M., 2017, Juvenile salmonid monitoring in the White Salmon River, Washington, post-Condit Dam removal, 2016: U.S. Geological Survey Open-File Report 2017-1070, 34 p., accessed January 18, 2018, at https://pubs.er.usgs.gov/publication/ofr20171070.

Jolley, J.C., Silver, G.S., Harris, J.E., and Whitessel, T.A., 2018, Pacific lamprey recolonization of a Pacific Northwest river following dam removal: River Research and Applications, v. 34, p. 44-51.

Kondolf, G.M., Anderson, S., Lave, R., Pagano, L., Merelender, A., and Bernhardt, E.S., 2007, Two decades of river restoration in California-What can we learn?: Restoration Ecology, v. 15 , p. $515-523$.

Lane and Lane Associates, 1981, White Salmon River Indian fisheries and Condit Dam: Portland, Oregon, Lane and Lane Associates with Douglas Nash, prepared for Bureau of Indian Affairs.

Lower Columbia Fish Recovery Board, 2010a, Research, monitoring and evaluation program for Lower Columbia salmon and steelhead: Lower Columbia Fish Recovery Board, 223 p., accessed November 28, 2016, at http://media.wix.com/ugd/810197_f87f5728a79b46ed9c508177e4ed4cf4.pdf.

Lower Columbia Fish Recovery Board, 2010b, Washington Lower Columbia salmon recovery and fish and wildlife subbasin plan: Lower Columbia Fish Recovery Board, 74 p., accessed November 28, 2016, at http://media.wix.com/ugd/810197_dec0786f0c474a1192fa14b45bde9be3.pdf.

McElhany, P., Ruckelshaus, M.H., Ford, M.J., Wainright, T.C., and Bjorkstedt, E.P., 2000, Viable salmonid populations and the recovery of evolutionarily significant units: National Oceanic and Atmospheric Administration Technical Memorandum, National Marine Fisheries Service-NWFSC-42, $146 \mathrm{p}$.

National Marine Fisheries Service, 2009, Middle Columbia River steelhead distinct population segment ESA recovery plan: Prepared by National Marine Fisheries Service Northwest Region, 260 p., accessed November 28, 2016, at http://www.westcoast.fisheries.noaa.gov/publications/recovery_planning/salmon_steelhead/do mains/interior_columbia/middle_columbia/mid-c-plan.pdf.

National Marine Fisheries Service, 2013a, ESA recovery plan for Lower Columbia River coho salmon, Lower Columbia River Chinook salmon, Columbia River chum salmon, and Lower Columbia River steelhead: Prepared by National Marine Fisheries Service Northwest Region, 503 p., accessed November 28, 2016, at http://www.westcoast.fisheries.noaa.gov/publications/recovery_planning/salmon_steelhead/do mains/willamette_lowercol/lower_columbia/final_plan_documents/final_lcr_plan_june_2013 -corrected.pdf.

National Marine Fisheries Service, 2013b, ESA recovery plan for the White Salmon River watershed: Prepared by National Marine Fisheries Service Northwest Region, 186 p., accessed November 28, 2016, at http://www.westcoast.fisheries.noaa.gov/publications/recovery_planning/salmon_steelhead/do mains/willamette_lowercol/lower_columbia/final_plan_documents/white_salmon_recovery_pl an_june_2013.pdf.

Northwest Power and Conservation Council, 2004, White Salmon subbasin plan: Portland, Oregon, Northwest Power and Conservation Council, 248 p., accessed December 12, 2016, at, https://www.nwcouncil.org/media/116777/EntirePlan.pdf. 
O’Connor, J.E., Duda, J.J., and Grant, G.E., 2015, 1,000 dams down and counting: Science, v. 348, p. 496-497.

Pess, G., 2009, Patterns and processes of salmon colonization: Seattle, University of Washington, Ph.D. dissertation.

Plummer, E., and Zuckerman, A., 2012, White Salmon River watershed anadromous fish passage inventory 2009-2011 survey report: Report prepared by Underwood Conservation District Report for Washington Salmon Recovery Funding Board, 35 p.

Quiñones, R.M., Grantham, T.E., Harvey, B.N., Kiernan, J.D., Klasson, M., Wintzer, A.P., and Moyle, P.B., 2015, Dam removal and anadromous salmonid (Oncorhynchus spp.) conservation in California: Reviews in Fish Biology and Fisheries, v. 25, p. 195-215.

Reiser, D.W., Huang, C., Beck, S., Gagner, M., and Jeanes E., 2006, Defining flow windows for upstream passage of adult anadromous salmonids at cascades and falls: Transactions of the American Fisheries Society, v. 135, p. 668-679.

Temple, G.M., and Pearsons, T.N., 2007, Electrofishing-Backpack and drift boat, in Johnson, D.H., Shrier, B.M., O`Neal, J.S., Knutzen, J.A., Augerot, X., O`Neil, T.A., and Pearsons, T.N., eds., Salmonid field protocols handbook-Techniques for assessing status and trends in salmon and trout populations: Bethesda, Maryland, American Fisheries Society, p. 95-132.

Thedinga, J.F., Murphy, M.L., Johnson, S.W., Lorenz, J.M., and Koski, K.V., 1994, Determination of salmonid smolt yield with rotary-screw traps in the Situk River, Alaska, to predict effects of glacial flooding: North American Journal of Fisheries Management, v. 14, p. 837-851.

Tullos, D.D., Collins, M.J., Bellmore, J.R., Bountry, J.A., Connolly, P.J., Shafroth, P.B., and Wilcox, A.C., 2016, Synthesis of common management concerns associated with dam removal: Journal of the American Water Resources Association, doi:10.1111/17521688.12450.

Volkhardt, G.C., Johnson, S.L., Miller, B.A., Nickelson, T.E., and Seiler, D.E. 2007, Rotary screw traps and inclined plane screen traps, in Johnson, D.H., Shrier, B.M., O’Neal, J.S., Knutzen, J.A., Augerot, X. O’Neal, T.A., and Pearsons, T.N., eds., Salmonid field protocols handbook-Techniques for assessing status and trends in salmon and trout populations: American Fisheries Society, p. 235-266.

Wilcox, A.C., O’Connor, J.E., and Major, J.J., 2014, Rapid reservoir erosion, hyperconcentrated flow, and downstream deposition triggered by breaching of $38 \mathrm{~m}$ tall Condit Dam, White Salmon River, Washington: Journal of Geophysical Research, Earth Surface, v. 119, doi:10.1002/2013JF003073.

Zendt, J., Romero, N., Keep, S., and Babcock, M., 2016, Klickitat subbasin monitoring and evaluation-Yakima/Klickitat fisheries project (YKFP), Annual Report for 2013-2015: Klickitat, Washington, Yakama Confederates Tribes, BPA Project Number 1995-063-35, 105 p., accessed December 20, 2016, at https://www.cbfish.org/Document.mvc/Viewer/P148516. 

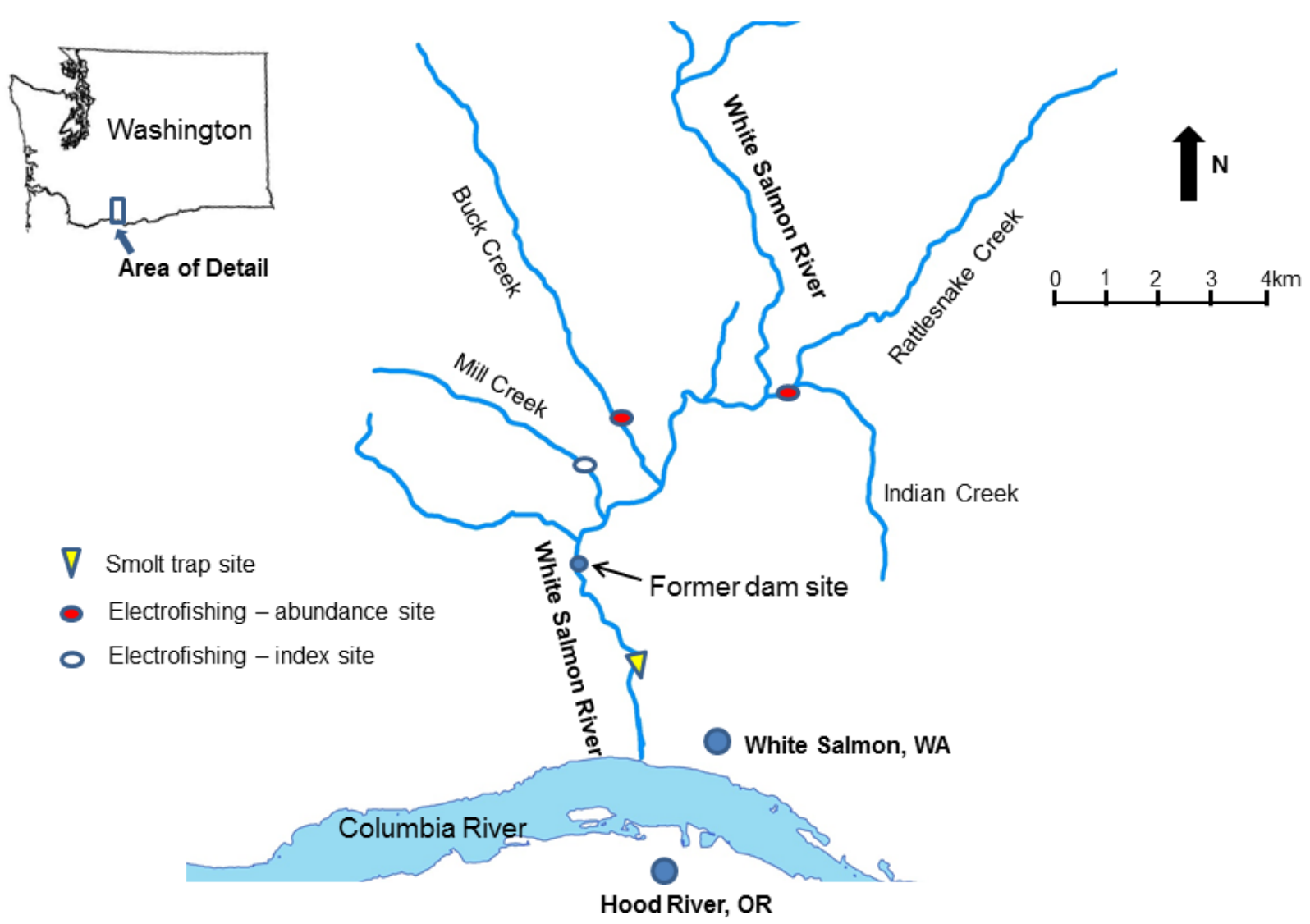

Figure 1. Schematic of the White Salmon River watershed accessible to anadromous salmonids showing locations of rotary screw trapping and electrofishing surveys during 2017 and the former location of Condit Dam, which was breached in 2011. 

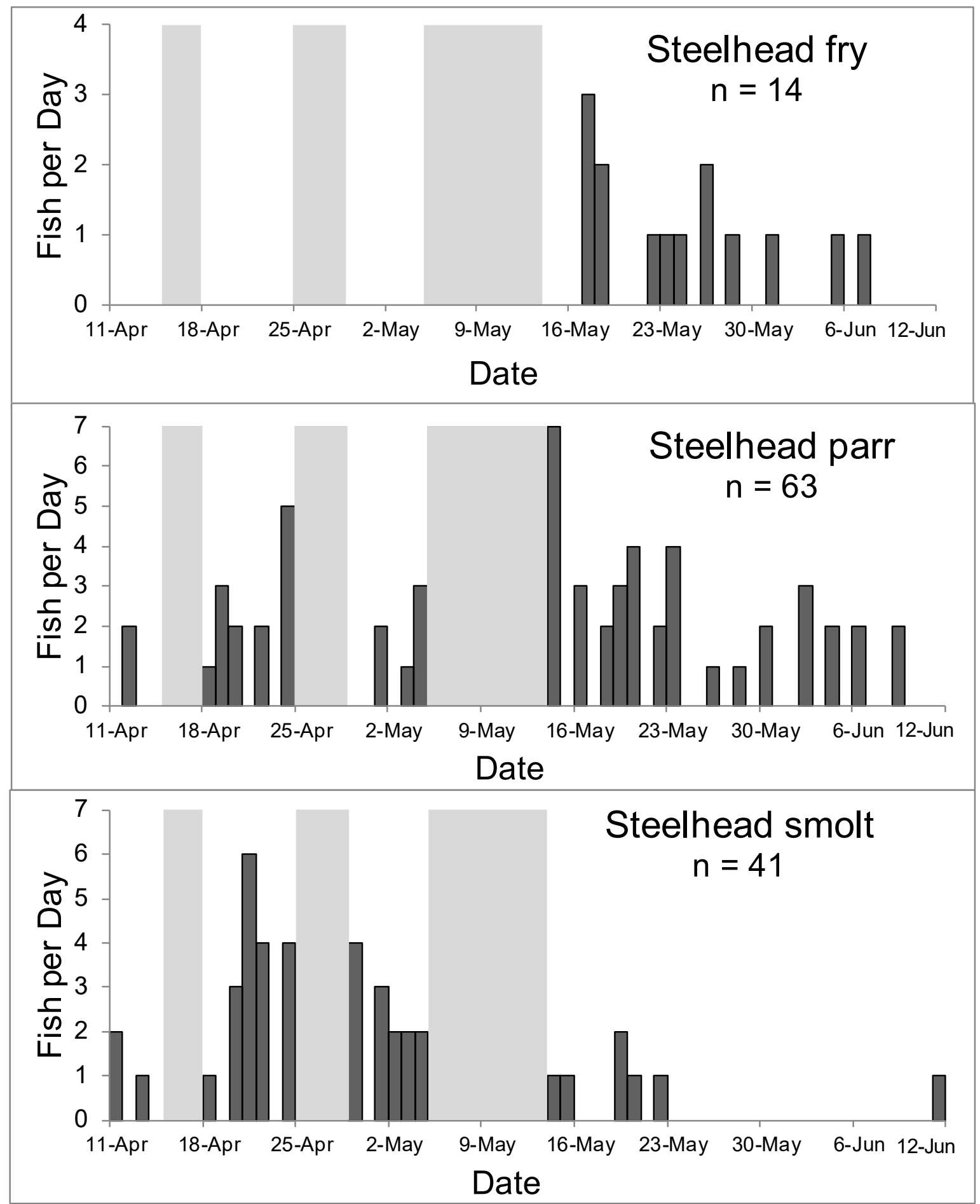

Figure 2. Graphs showing daily catch of steelhead (Oncorhynchus mykiss) fry (upper graph), parr (middle graph), and smolts (lower graph) in the screw trap at river kilometer 2.3, White Salmon River, Washington, April 11-June 12, 2017. Light gray shading indicates when the screw trap was not operated during April 15-17, April 25-28, and May $5-13,2017$. Note that the scale on the y axis differs between the upper graph and the other two graphs. 

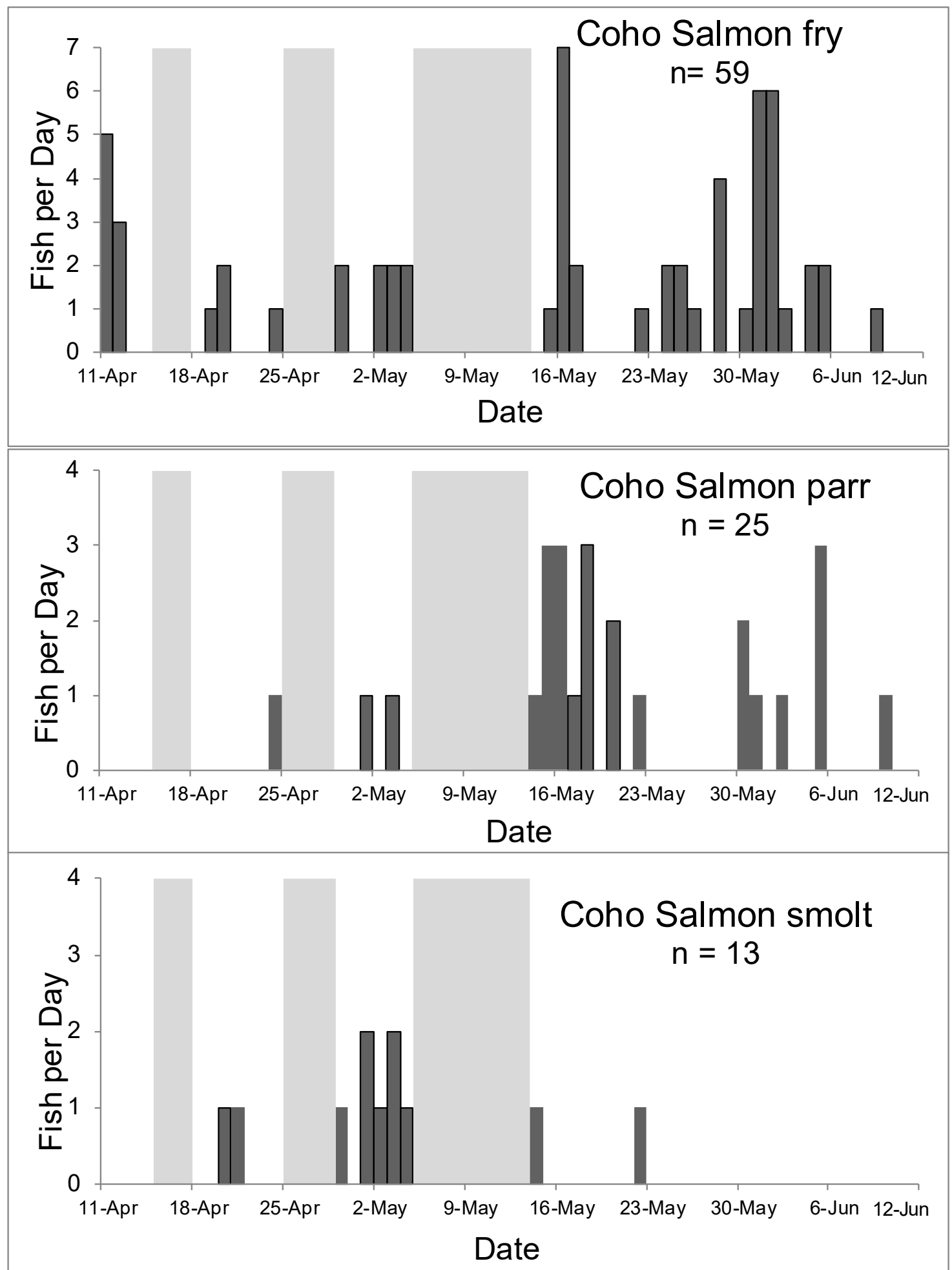

Figure 3. Graphs showing daily catch of coho salmon (Oncorhynchus kisutch) fry (upper graph), parr (middle graph), and smolt (lower graph) in the screw trap at river kilometer 2.3, White Salmon River, Washington, April 11-June 12, 2017. Light gray shading indicates when the screw trap was not operated during April 15-17, April 25-28, and May 5-13, 2017. Note that scale on the y axis differs between the upper graph and the other two graphs. 


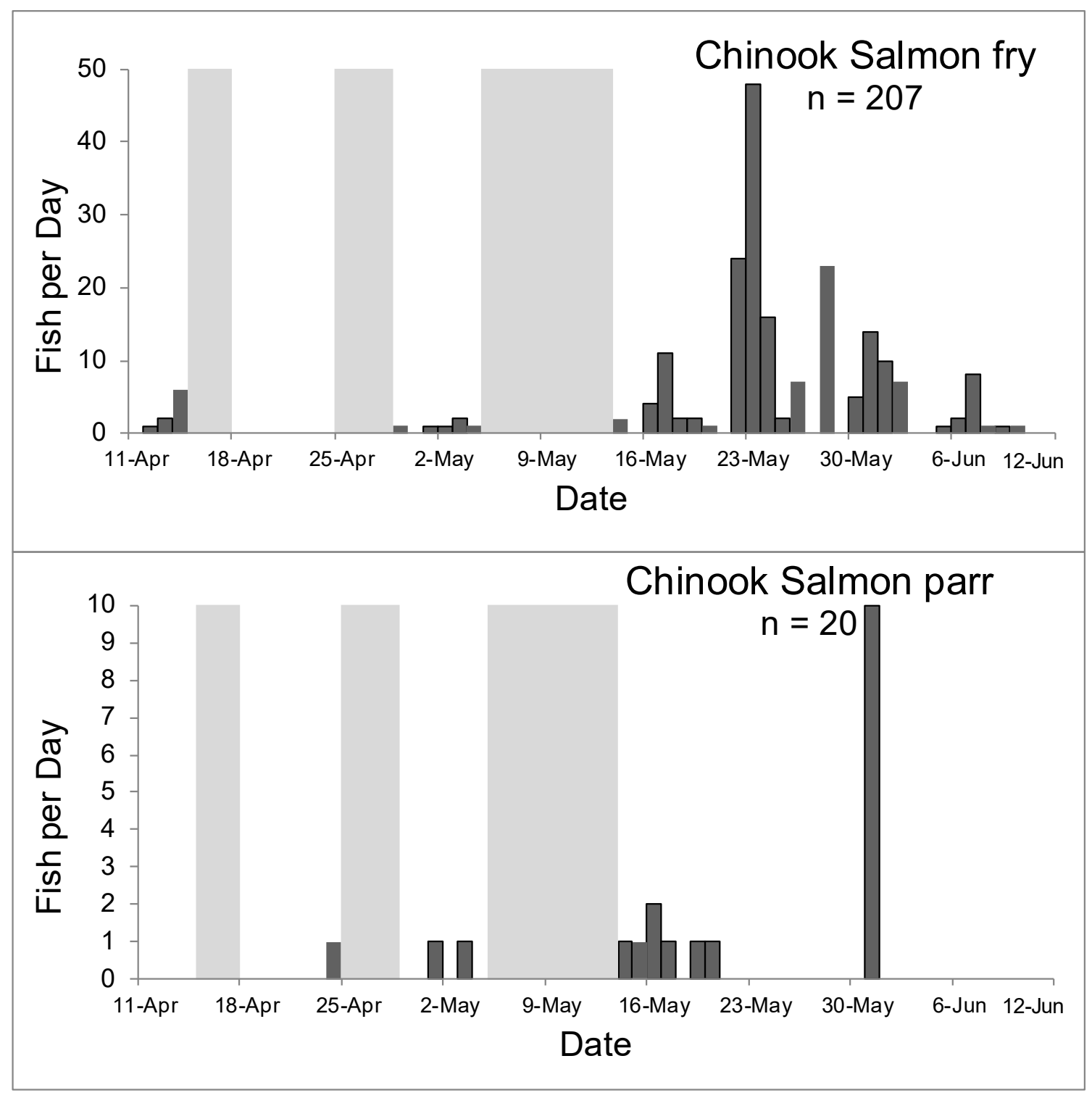

Figure 4. Graph showing daily catch of Chinook salmon (Oncorhynchus tshwaytscha) fry (upper graph) and parr (lower graph) in the screw trap at river kilometer 2.3, White Salmon River, Washington, April 11-June 12, 2017. Only one Chinook Salmon smolt was captured on May 26, 2017. Light gray shading indicates when the screw trap was not operated during April 15-17, April 25-28, and May 5-13, 2017. Note that the scale on the y axis differs between graphs. 

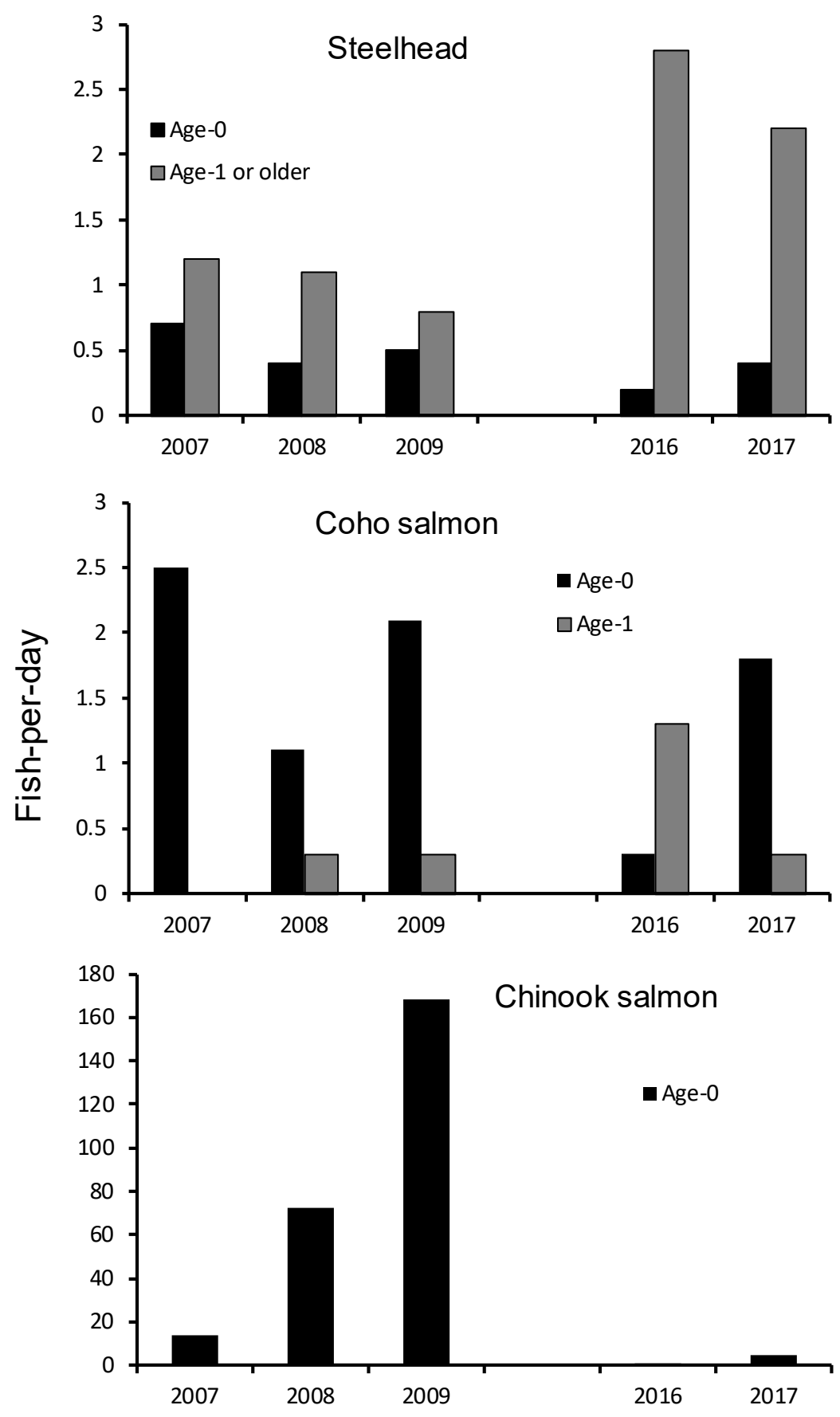

Figure 5. Graphs showing fish-per-day (number captured/days fished) of steelhead (Oncorhynchus mykiss; upper graph), coho salmon ( 0 . kisutch; middle graph), and Chinook salmon (O. tshwaytscha; bottom graph) at a screw trap fished prior to (2007-09) and after (2016-17) removal of Condit Dam, White Salmon River, Washington. Screw trap was located at river kilometer ( $\mathrm{rkm}) 1.5$ prior to dam removal and at rkm 2.3 after dam removal. Much of the Chinook salmon spawning in the White Salmon River occurs downstream of rkm 2.3. Two age classes are shown for steelhead and coho salmon. Fewer than 0.15 age-1 Chinook salmon per day were captured in all years. Note that scale on the y axis differs between the upper two graphs and the other graph. 


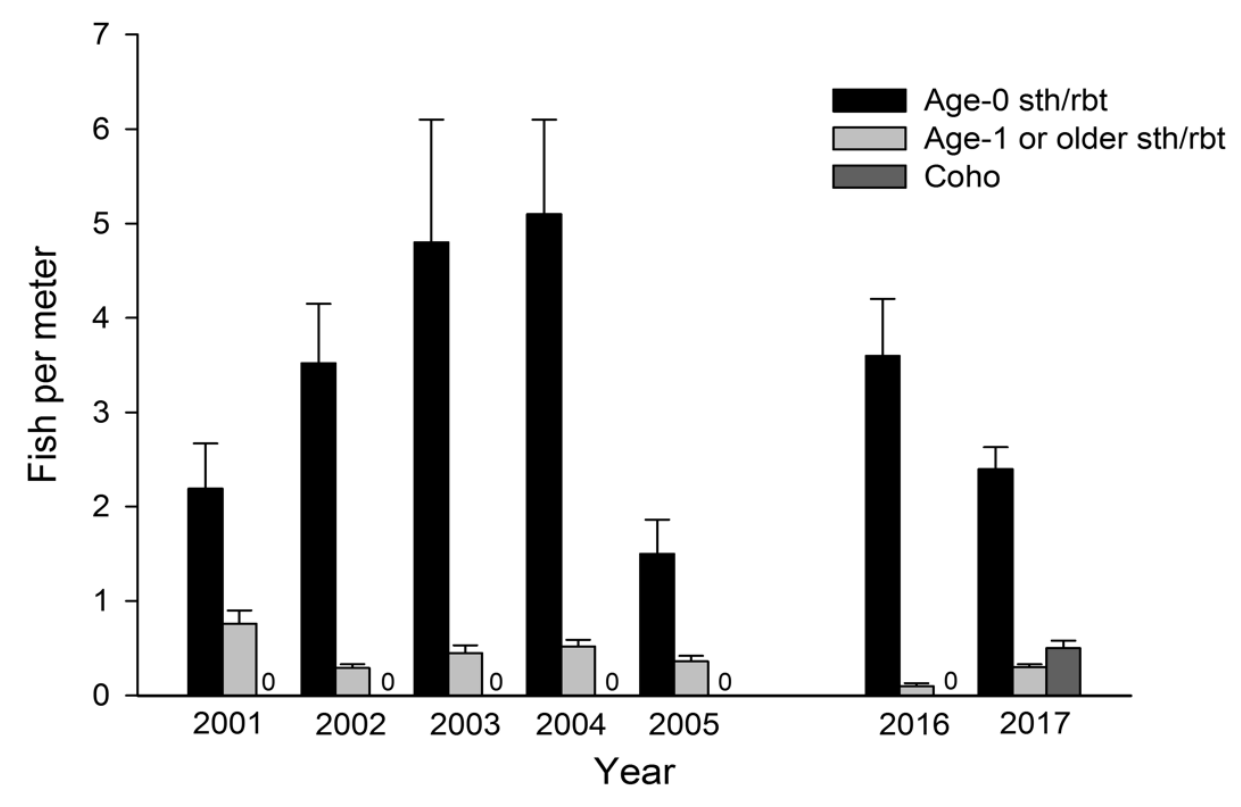

Figure 6. Graph showing abundance estimates (fish per meter) of steelhead/rainbow trout (sth/rbt; Oncorhynchus mykiss) and coho salmon (O. kisutch) at a site on the lower kilometer of Rattlesnake Creek, Washington, 2001-05 and 2016-17. Estimates are shown for 5 years (2001-05) prior to removal of Condit Dam from the White Salmon River (breached in 2011), and after dam removal (2016-17). Error bars indicate standard error. 


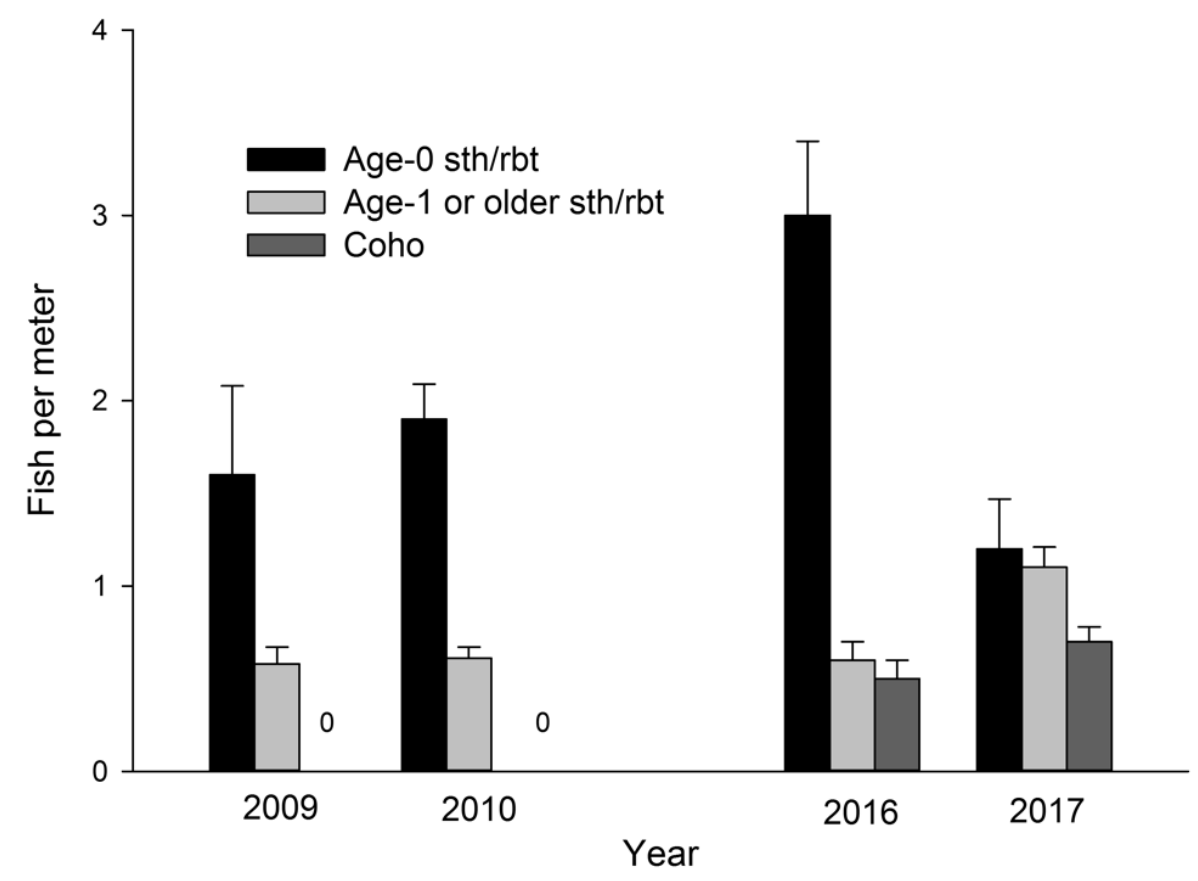

Figure 7. Graph showing abundance estimates (fish per meter) of steelhead/rainbow trout (sth/rbt; Oncorhynchus mykiss) and coho salmon (0. kisutch) at a sample site in river kilometer 2 of Buck Creek, Washington, 2009-10 and 2016-17. Estimates are shown for 2 years prior to removal of Condit Dam from the White Salmon River (breached in 2011), and after dam removal (2016-17). Error bars indicate standard error. 
Table 1. Latitude and longitude (decimal degrees) of fish sampling sites, White Salmon River watershed, Washington, 2017.

[Sample type: Ef. Dist., electrofishing distribution survey; Ef. Ab., electrofishing abundance survey. End point: NA, not applicable]

\begin{tabular}{|c|c|c|c|c|c|c|}
\hline \multirow{3}{*}{ Site } & \multirow{3}{*}{ Date } & \multirow{3}{*}{$\begin{array}{c}\text { Sample } \\
\text { type }\end{array}$} & \multicolumn{4}{|c|}{ Sample site coordinates } \\
\hline & & & \multicolumn{2}{|c|}{ Start point } & \multicolumn{2}{|c|}{ End point } \\
\hline & & & Latitude & Longitude & Latitude & Longitude \\
\hline White Salmon $^{1}$ & $04-11-6-12-2017$ & Screw trap ${ }^{2}$ & 45.74764 & -121.52110 & NA & NA \\
\hline Mill Creek & 09-14-2017 & Ef. Dist. & 45.78386 & -121.53582 & 45.78647 & -121.53821 \\
\hline Buck Creek & $08-28,29-2017$ & $\mathrm{Ef} . \mathrm{Ab}$. & 45.79603 & -121.52914 & 45.79776 & -121.52980 \\
\hline Rattlesnake Creek & $08-30,31-2017$ & Ef. Ab. & 45.79759 & -121.48174 & 45.79780 & -121.47903 \\
\hline
\end{tabular}

${ }^{1}$ The White Salmon River screw trap operated intermittently from April 11 to June 12, 2017.

${ }^{2}$ Screw trap was a fixed sampling location.

Table 2. Number of steelhead (Oncorhynchus mykiss), Chinook salmon (O. tshawytscha), and coho salmon ( 0 . kisutch), by life stage, captured, tagged with passive integrated transponder (PIT) tags, and sampled for genetic material at the screw trap at river kilometer 2.3, White Salmon River, Washington, April 11, 2017-June 12, 2017.

[Fry were 45-millimeter fork length or less. N: Number of samples. Gen.: Fin tissue sample taken for genetic analysis. NA, not applicable; fry were not PIT-tagged]

\begin{tabular}{|c|c|c|c|c|c|c|c|c|c|c|}
\hline \multirow[b]{2}{*}{ Year } & \multirow[b]{2}{*}{$\begin{array}{l}\text { Life } \\
\text { stage }\end{array}$} & \multicolumn{3}{|c|}{ Steelhead } & \multicolumn{3}{|c|}{ Chinook salmon } & \multicolumn{3}{|c|}{ Coho salmon } \\
\hline & & $\mathrm{N}$ & $\begin{array}{c}\text { PIT- } \\
\text { tagged }\end{array}$ & Gen. & $\mathrm{N}$ & $\begin{array}{c}\text { PIT- } \\
\text { tagged }\end{array}$ & Gen. & $\mathrm{N}$ & $\begin{array}{c}\text { PIT- } \\
\text { tagged }\end{array}$ & Gen. \\
\hline${ }^{1} 2016$ & Fry & 9 & NA & NA & 4 & NA & 2 & 19 & NA & 17 \\
\hline 2016 & Parr & 23 & 20 & 21 & 0 & 0 & 0 & 2 & NA & 2 \\
\hline 2016 & Smolt & 153 & 150 & 149 & 0 & 0 & 0 & 82 & 79 & 79 \\
\hline 2016 & Total & 185 & 170 & 170 & 4 & 0 & 2 & 103 & 79 & 98 \\
\hline${ }^{1} 2017$ & Fry & 14 & NA & 1 & 203 & 0 & 124 & 59 & 1 & 0 \\
\hline 2017 & Parr & 61 & 57 & 59 & 19 & 3 & 16 & 21 & 11 & 0 \\
\hline 2017 & Smolt & 40 & 39 & 40 & 1 & 1 & 1 & 13 & 11 & 2 \\
\hline 2017 & Total & 115 & 96 & 100 & 223 & 4 & 141 & 93 & 23 & 1 \\
\hline
\end{tabular}

${ }^{1}$ The trap was fished for 62 days in 2016 and for 45 days in 2017. 
Table 3. Number of steelhead (Oncorhynchus mykiss) and coho salmon (0. kisutch) smolt, and age-0 Chinook salmon captured, marked, and recaptured at the smolt trap at river kilometer 2.3, White Salmon River, Washington, March 24-May 28, 2016, and April 11-June 12, 2017.

[Smolt estimates are shown for steelhead and coho salmon during 2016. Because of prolonged high water and missed trapping days during 2017, we could not generate estimates. SE: standard error. 95-percent CI: 95-percent confidence interval. NA, not applicable.]

\begin{tabular}{|c|c|c|c|c|c|c|}
\hline $\begin{array}{c}\text { Year } \\
\text { and species }\end{array}$ & $\begin{array}{l}\text { Number } \\
\text { captured }\end{array}$ & $\begin{array}{l}\text { Number } \\
\text { of fish } \\
\text { marked }\end{array}$ & $\begin{array}{c}\text { Number } \\
\text { of fish } \\
\text { recaptured }\end{array}$ & Estimate & SE & 95-percent $\mathrm{Cl}$ \\
\hline \multicolumn{7}{|l|}{$2016^{1}$} \\
\hline Steelhead & 153 & 150 & 5 & 3,851 & 1,454 & $1,001-6,700$ \\
\hline Coho & 82 & 79 & 5 & 1,093 & 412 & $286-1,900$ \\
\hline Age-0 Chinook & 4 & 0 & NA & NA & NA & NA \\
\hline \multicolumn{7}{|l|}{$2017^{1}$} \\
\hline Steelhead & 40 & 39 & 1 & NA & NA & NA \\
\hline Coho & 13 & 12 & 0 & NA & NA & NA \\
\hline Age-0 Chinook & 222 & 192 & 4 & NA & NA & NA \\
\hline
\end{tabular}

${ }^{1}$ The trap was fished for 62 days in 2016 and for 45 days in 2017.

Table 4. Number of juvenile salmonids captured and tagged with passive integrated transponder (PIT) tags, and tissue sampled for genetic analysis during electrofishing surveys, White Salmon River watershed, Washington, 2017.

[Species: Sth/Rbt, Oncorhynchus mykiss (steelhead or rainbow trout); Trout, trout fry that could not be differentiated between cutthroat trout (O. clarkii) or O. mykiss. Gen.: Fin tissue taken for genetic analysis. $\geq$, greater than or equal to]

\begin{tabular}{rcccccrrr}
\hline Site & Dates & $\begin{array}{c}\text { Site start } \\
\text { (river } \\
\text { kilometer) }\end{array}$ & $\begin{array}{c}\text { Sampled } \\
\text { length } \\
\text { (meter) }\end{array}$ & Species & $\begin{array}{c}\text { Age } \\
\text { (year) }\end{array}$ & Catch & $\begin{array}{c}\text { PIT } \\
\text { tagged }\end{array}$ & Gen. \\
\hline Mill Creek & $09-14-2017$ & 1.3 & 250 & Trout & 0 & 14 & 1 & 7 \\
Mill Creek & $09-14-2017$ & 1.3 & 250 & Sth/Rbt & $\geq 1$ & 4 & 4 & 2 \\
Mill Creek & $09-14-2017$ & 1.3 & 250 & Cutthroat & $\geq 1$ & 34 & 33 & 28 \\
Mill Creek & $09-14-2017$ & 1.3 & 250 & Coho & 0 & 1 & 1 & 1 \\
& & & & & & & & \\
Buck Creek & $08-28,29-2017$ & 2.0 & 230 & Trout & 0 & 104 & 31 & 37 \\
Buck Creek & $08-28,29-2017$ & 2.0 & 230 & Sth/Rbt & $\geq 1$ & 155 & 144 & 11 \\
Buck Creek & $08-28,29-2017$ & 2.0 & 230 & Cutthroat & $\geq 1$ & 1 & 1 & 0 \\
Buck Creek & $08-28,29-2017$ & 2.0 & 230 & Coho & 0 & 114 & 105 & 0 \\
& & & & & & & & \\
Rattlesnake Creek & $08-30,31-2017$ & 0.3 & 223 & Trout & 0 & 280 & 211 & 37 \\
Rattlesnake Creek & $08-30,31-2017$ & 0.3 & 223 & Sth/Rbt & $\geq 1$ & 57 & 54 & 7 \\
Rattlesnake Creek & $08-30,31-2017$ & 0.3 & 223 & Cutthroat & $\geq 1$ & 2 & 2 & 0 \\
Rattlesnake Creek & $08-30,31-2017$ & 0.3 & 223 & Coho & 0 & 71 & 65 & 0 \\
\hline
\end{tabular}


Table 5. Abundance estimates and standard error, abundance (fish per meter) and density (fish per meter squared) of steelhead/rainbow trout (Oncorhynchus mykiss) and coho salmon (0. kisutch) at abundance electrofishing sites in Buck and Rattlesnake Creeks, Washington, August 2017.

[Site and species: Sth/Rbt, O. mykiss (steelhead or rainbow trout); Trout, trout fry that could not be differentiated between cutthroat trout or O. mykiss. SE: standard error for abundance estimate column to left. $\geq$, greater than or equal to)

\begin{tabular}{rrrrrrrrr}
\hline $\begin{array}{c}\text { Site } \\
\text { and species }\end{array}$ & $\begin{array}{c}\text { Age } \\
\text { (year) }\end{array}$ & $\begin{array}{c}\text { Number } \\
\text { of fish } \\
\text { marked }\end{array}$ & $\begin{array}{c}\text { Number } \\
\text { of fish } \\
\text { captured }\end{array}$ & $\begin{array}{c}\text { Number } \\
\text { of fish } \\
\text { recaptured }\end{array}$ & $\begin{array}{c}\text { Abundance } \\
\text { estimate }\end{array}$ & SE & $\begin{array}{c}\text { Fish } \\
\text { per } \\
\text { meter }\end{array}$ & $\begin{array}{c}\text { Fish per } \\
\text { meter } \\
\text { squared }\end{array}$ \\
\hline Buck Creek & & & & & & & & \\
Trout & 0 & 61 & 54 & 11 & 284 & 62.6 & 1.2 & 0.20 \\
Sth/Rbt & $\geq 1$ & 92 & 106 & 37 & 262 & 25.9 & 1.1 & 0.18 \\
Coho & 0 & 75 & 62 & 27 & 171 & 18.8 & 0.7 & 0.12 \\
Rattlesnake Creek & & & & & & & & \\
Trout & 0 & 165 & 157 & 49 & 525 & 50.8 & 2.4 & 0.35 \\
Sth/Rbt & $\geq 1$ & 41 & 34 & 20 & 70 & 6.7 & 0.3 & 0.05 \\
Coho & 0 & 45 & 39 & 15 & 115 & 17.4 & 0.5 & 0.08 \\
\hline
\end{tabular}




\section{Appendix 1. Length Frequencies}

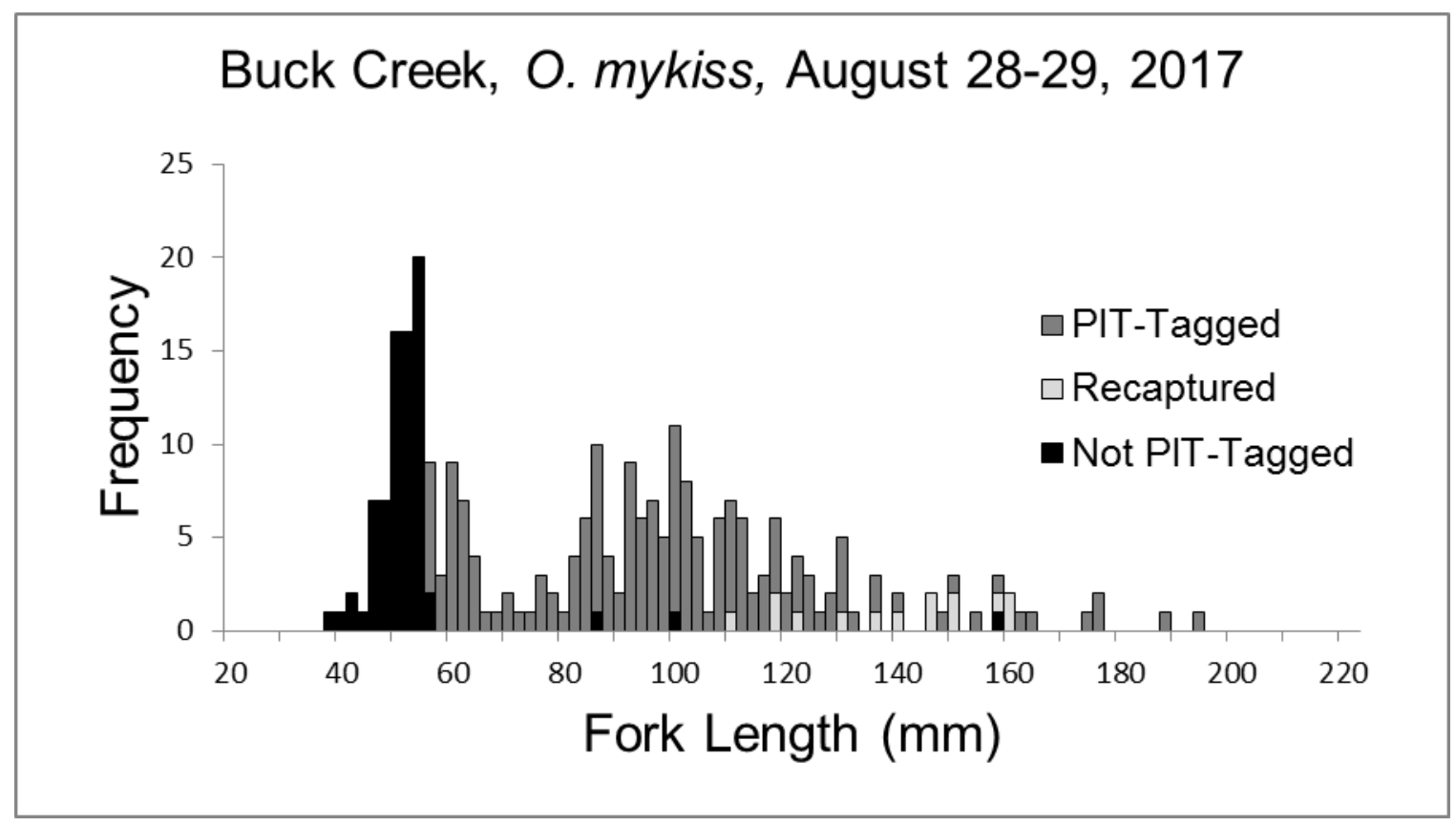

Figure 1.1. Graph showing length frequency in 2-millimeter $(\mathrm{mm})$ increments of steelhead/rainbow trout (Oncorhynchus mykiss) sampled in a 230-meter section at river kilometer 2, Buck Creek, Washington, 2017. Recaptured fish had been passive integrated transponder-tagged (PIT-tagged) in 2016.

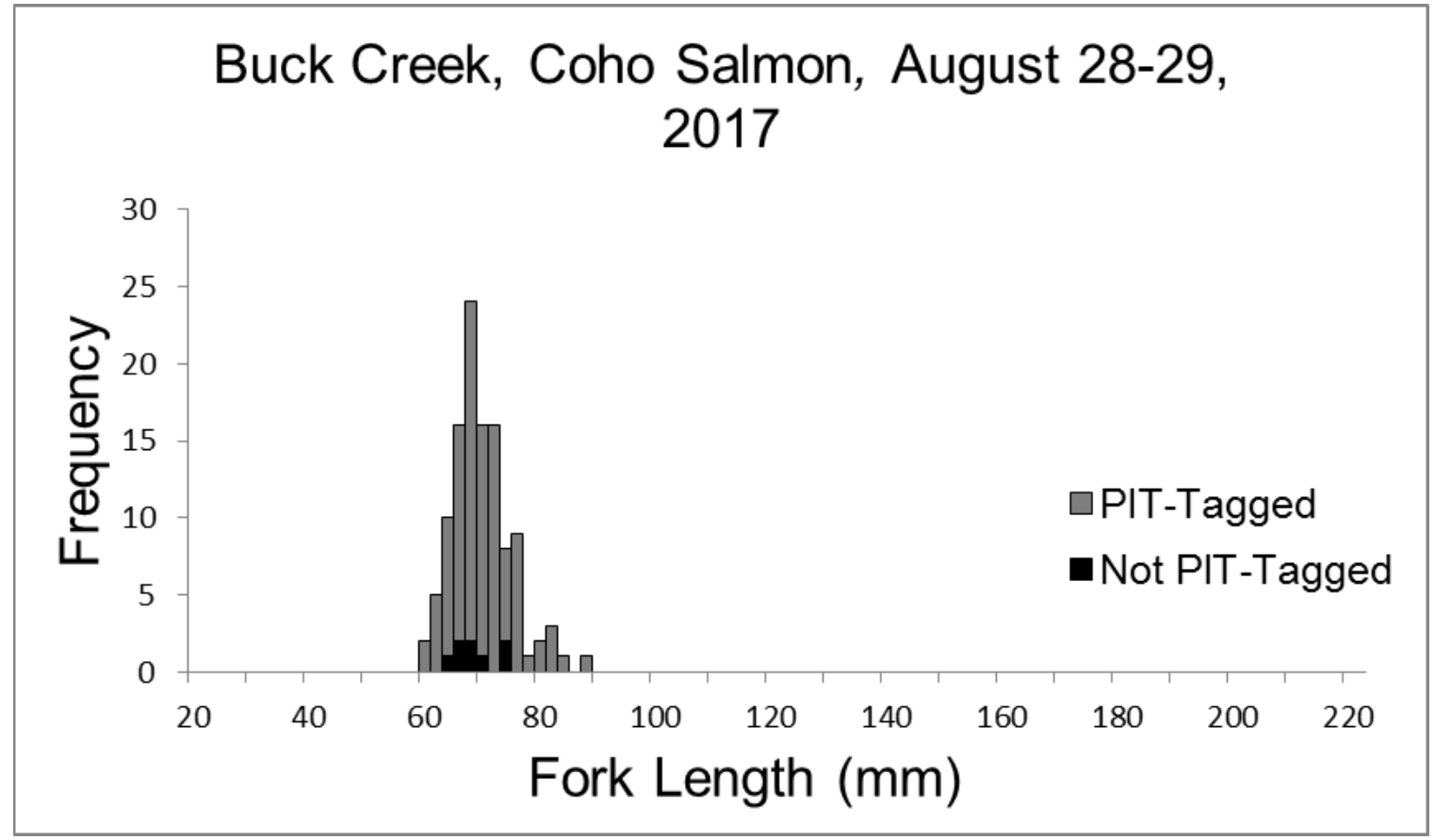

Figure 1.2. Graph showing length frequency in 2-millimeter $(\mathrm{mm})$ increments of coho salmon (Oncorhynchus kisutch) sampled in a 230-meter section at river kilometer 2, Buck Creek, Washington, 2017. PIT, passive integrated transponder. 


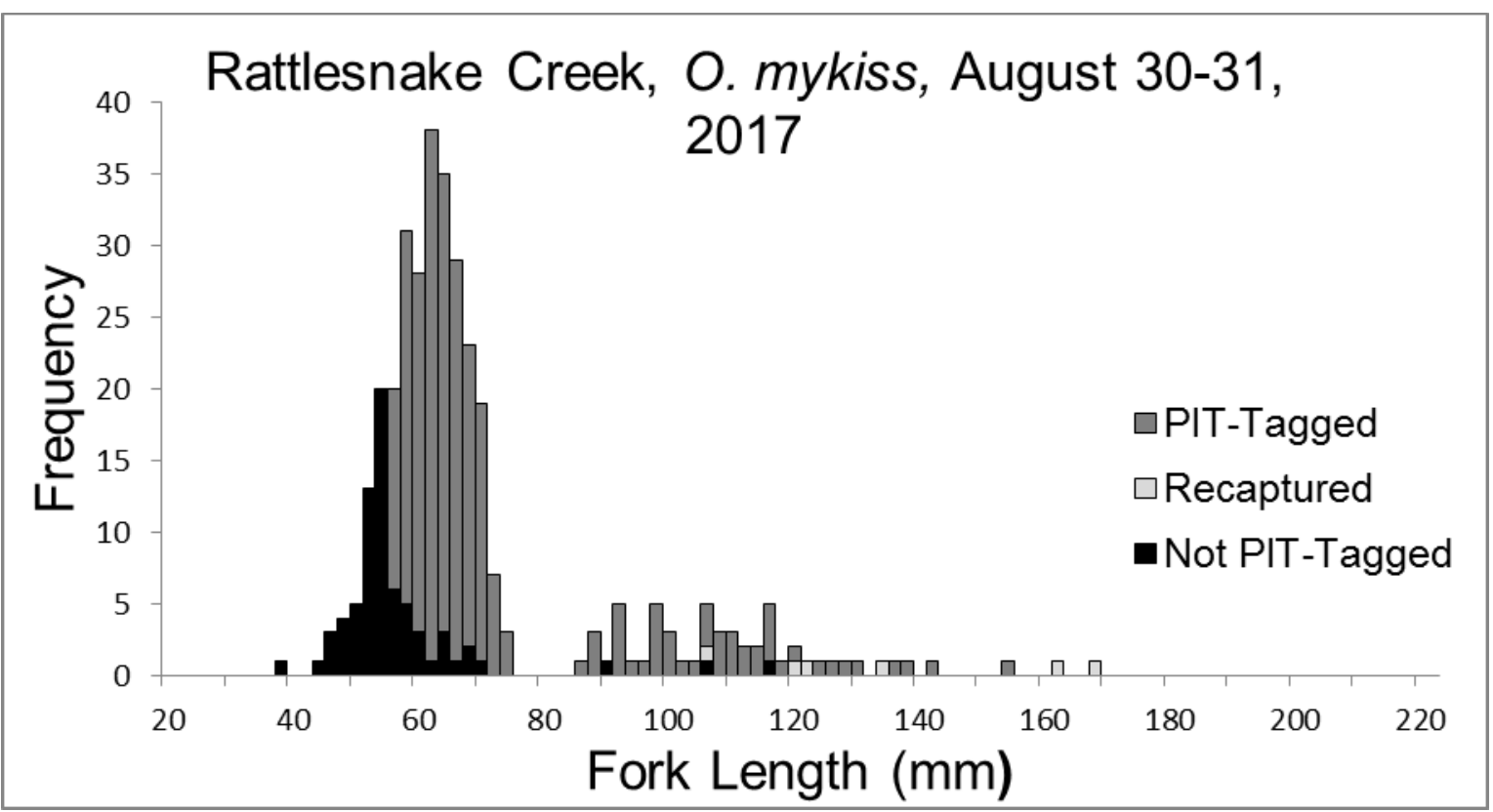

Figure 1.3. Graph showing length frequency in 2-millimeter $(\mathrm{mm})$ increments of steelhead/rainbow trout (Oncorhynchus mykiss) sampled in a 223-meter section at river kilometer 0.3, Rattlesnake Creek, Washington, 2017. Recaptured fish had been passive integrated transponder-tagged (PIT-tagged) in 2016.

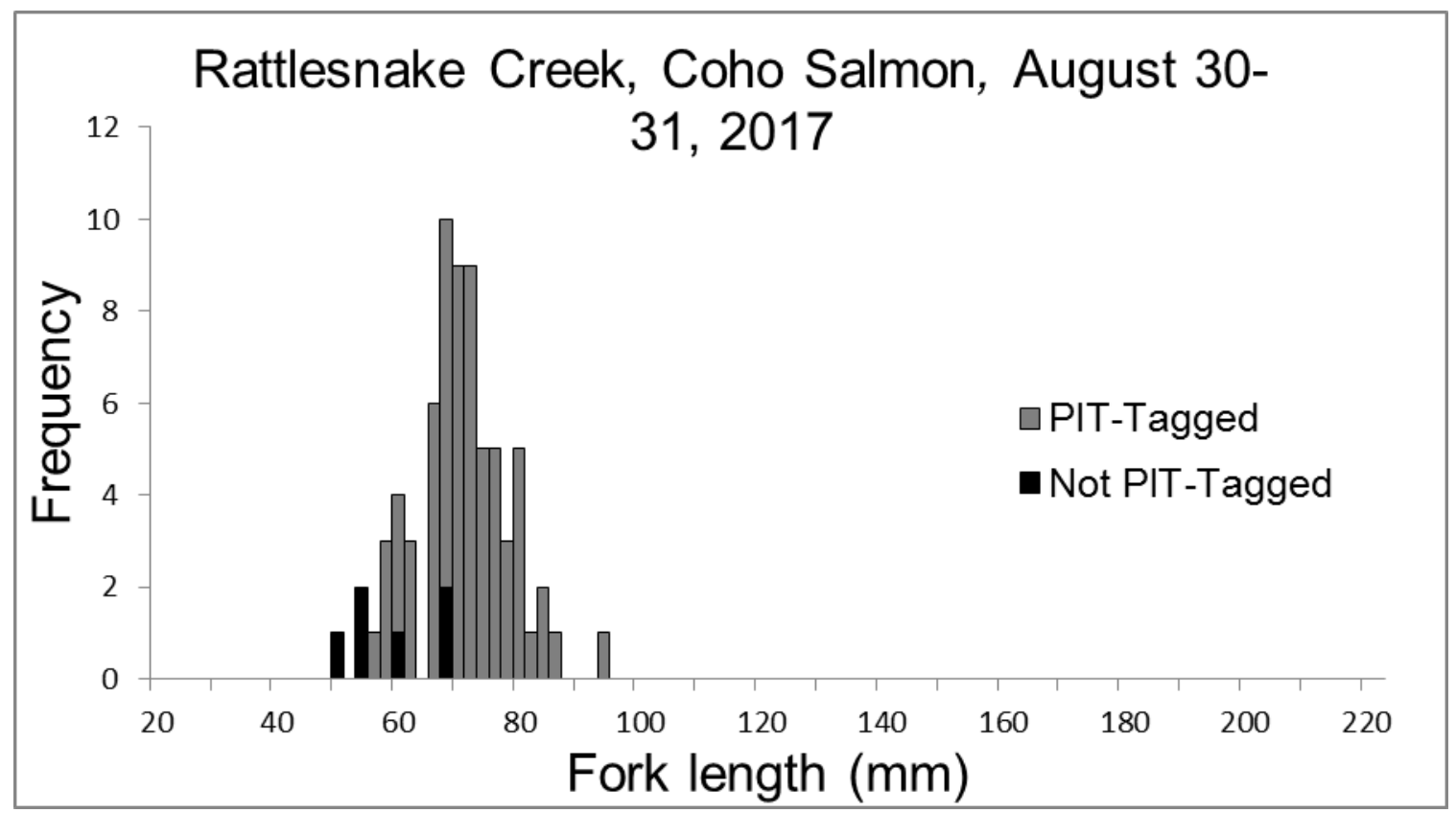

Figure 1.4. Graph showing length frequency in 2-millimeter $(\mathrm{mm})$ increments of coho salmon (Oncorhynchus kisutch) sampled in a 223-meter section at river kilometer 0.3, Rattlesnake Creek, Washington, 2017. Recaptured fish had been passive integrated transponder-tagged (PIT-tagged) in 2016. 


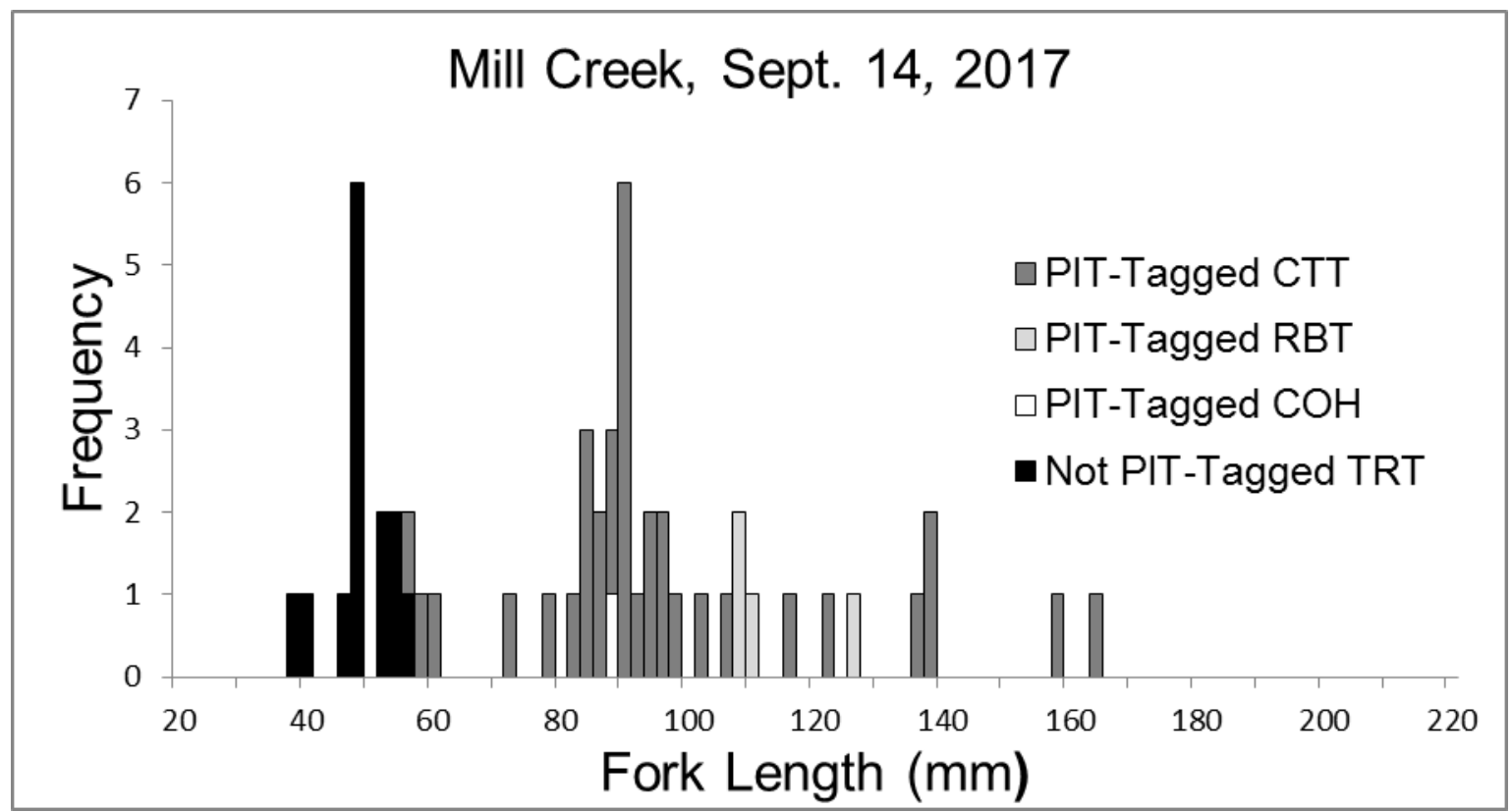

Figure 1.5. Graph showing length frequency in 2-millimeter $(\mathrm{mm})$ increments of steelhead/rainbow trout (RBT; Oncorhynchus mykiss), cutthroat trout (CTT; O. clarkii), and a coho salmon (COH; O. kisutch) sampled in a 250-meter section at river kilometer 1.2, Mill Creek, Washington, 2017. Trout (TRT) are trout fry that could not be differentiated between cutthroat trout or 0 . mykiss, and were less than $55 \mathrm{~mm}$ fork length. Note that one trout fry was passive integrated transponder -tagged (PIT-tagged) at a fork length of $55 \mathrm{~mm}$, and one cutthroat trout was not PIT-tagged (fork length of $89 \mathrm{~mm}$ ). 
Publishing support provided by the U.S. Geological Survey

Science Publishing Network, Tacoma Publishing Service Center

For more information concerning the research in this report, contact the Director, Western Fisheries Research Center

U.S. Geological Survey

6505 NE 65th Street

Seattle, Washington 98115

https://wfrc.usgs.gov/ 
